\title{
Clay mineralogy, strontium and neodymium isotope ratios in the sediments of two High Arctic catchments (Svalbard)
}

\author{
Ruth S. Hindshaw ${ }^{1}$, Nicholas J. Tosca ${ }^{2}$, Alexander M. Piotrowski ${ }^{1}$, and Edward T. Tipper ${ }^{1}$ \\ ${ }^{1}$ Department of Earth Sciences, University of Cambridge, Downing Street, Cambridge, UK, CB2 3EQ \\ ${ }^{2}$ Department of Earth Sciences, University of Oxford, South Parks Road, Oxford, UK, OX1 3AN
}

Correspondence: Ruth S. Hindshaw (ruth.hindshaw@gmail.com)

Received: 12 September 2017 - Discussion started: 19 September 2017

Revised: 9 January 2018 - Accepted: 6 February 2018 - Published: 5 March 2018

\begin{abstract}
The identification of sediment sources to the ocean is a prerequisite to using marine sediment cores to extract information on past climate and ocean circulation. $\mathrm{Sr}$ and $\mathrm{Nd}$ isotopes are classical tools with which to trace source provenance. Despite considerable interest in the Arctic Ocean, the circum-Arctic source regions are poorly characterised in terms of their $\mathrm{Sr}$ and $\mathrm{Nd}$ isotopic compositions. In this study we present $\mathrm{Sr}$ and $\mathrm{Nd}$ isotope data from the Paleogene Central Basin sediments of Svalbard, including the first published data of stream suspended sediments from Svalbard.

The stream suspended sediments exhibit considerable isotopic variation $(\varepsilon \mathrm{Nd}=-20.6$ to -13.4 ; ${ }^{87} \mathrm{Sr} /{ }^{86} \mathrm{Sr}=0.73421$ to 0.74704 ) which can be related to the depositional history of the sedimentary formations from which they are derived. In combination with analysis of the clay mineralogy of catchment rocks and sediments, we suggest that the Central Basin sedimentary rocks were derived from two sources. One source is Proterozoic sediments derived from Greenlandic basement rocks which are rich in illite and have high ${ }^{87} \mathrm{Sr} /{ }^{86} \mathrm{Sr}$ and low $\varepsilon \mathrm{Nd}$ values. The second source is Carboniferous to Jurassic sediments derived from Siberian basalts which are rich in smectite and have low ${ }^{87} \mathrm{Sr} /{ }^{86} \mathrm{Sr}$ and high $\varepsilon \mathrm{Nd}$ values. Due to a change in depositional conditions throughout the Paleogene (from deep sea to continental) the relative proportions of these two sources vary in the Central Basin formations. The modern stream suspended sediment isotopic composition is then controlled by modern processes, in particular glaciation, which determines the present-day exposure of the formations and therefore the relative contribution of each formation to the stream suspended sediment load. This study demonstrates that the $\mathrm{Nd}$ isotopic composition of stream suspended sediments exhibits seasonal variation, which likely mirrors longer-term hydrological changes, with implications for source provenance studies based on fixed endmembers through time.
\end{abstract}

\section{Introduction}

Since the Miocene, the Arctic has been subject to the repeated advance and retreat of ice sheets, a record of which is preserved in ocean sediments (Svendsen et al., 2004; Knies and Gaina, 2008). Thus, the Arctic Ocean and its surrounding seas are a key region for developing our understanding of past ice sheet dynamics and climate. A considerable number of ocean cores have been drilled in this region, allowing us to access the sedimen- tary archive (e.g. Vogt et al., 2001; Spielhagen et al., 2004; Knies and Gaina, 2008; Hillaire-Marcel et al., 2013; Fagel et al., 2014; Meinhardt et al., 2016). They provide information on past ocean chemistry through analysis of foraminifera (e.g. Knies et al., 2014), on iceberg abundance through analysis of ice-rafted debris (IRD, e.g. Spielhagen et al., 2004) and on past sediment sources through analysis of the mineralogy and geochemistry of the sediment (e.g. Meinhardt et al., 2016). 
Clay mineralogy in ocean sediment cores is often used to reconstruct paleoclimate and paleoceanography (e.g. Winkler et al., 2002). However, both the source rock and weathering conditions on the continents affect which clay minerals are formed. For example, kaolinite is more likely to form in tropical climates with intense chemical weathering, whereas illite is more likely to form where physical weathering dominates (Singer, 1984). The weathering of basalt will likely lead to the formation of smectite, whereas the weathering of granite will likely lead to the formation of illite or kaolinite (Essington, 2004). The Arctic Ocean has a wide variety of source regions (geographical regions with relatively homogenous lithology) ranging from Siberia (young basalts) to Greenland (Precambrian rocks) and it is therefore imperative for paleoclimate studies to identify which changes in clay mineralogy are related to a change in climate and which are related to a change in source region.

The radiogenic isotope tracers ${ }^{143} \mathrm{Nd} /{ }^{144} \mathrm{Nd}$ (expressed as $\varepsilon \mathrm{Nd}$ ) and ${ }^{87} \mathrm{Sr} /{ }^{86} \mathrm{Sr}$ are often used together to understand where and how sediment is generated and weathered, enabling source regions to be characterised (Goldstein and Jacobsen, 1988; Cameron and Hattori, 1997; Tricca et al., 1999; Peucker-Ehrenbrink et al., 2010; Lupker et al., 2013; Clinger et al., 2016). $\varepsilon \mathrm{Nd}$ is particularly suited to being a source tracer because, unlike $\mathrm{Sr}$ and $\mathrm{Rb}$ which are fluid mobile, $\mathrm{Sm}$ and $\mathrm{Nd}$ are immobile and behave very similarly during chemical weathering such that the Sm / Nd ratio does not fractionate during weathering (McCulloch and Wasserburg, 1978) and therefore variations in $\varepsilon \mathrm{Nd}$ are predominantly controlled by age (Goldstein and Jacobsen, 1988) rather than the weathering of specific minerals which can affect the $\mathrm{Rb}-\mathrm{Sr}$ system (e.g. Bullen et al., 1997).

Although weathering effects on the neodymium isotopic composition of sediments are considered essentially negligible, it has been shown that in certain circumstances preferential leaching of minerals with a different $\mathrm{Sm} / \mathrm{Nd}$ ratio to bulk rock can lead to variations in $\varepsilon \mathrm{Nd}$ in soil profiles (Öhlander et al., 2000; Aubert et al., 2001), which could affect the $\varepsilon \mathrm{Nd}$ value of the derived sediments. Variations within soil profiles are either attributed to dust inputs (Viers and Wasserburg, 2004; Ma et al., 2010) and/or the dissolution of accessory phases such as phosphate minerals or Fe-Mn oxyhydroxides (Goldstein and Jacobsen, 1987; Öhlander et al., 2000; Aubert et al., 2001; Babechuk et al., 2015). Additionally, $\varepsilon \mathrm{Nd}$ variations in ocean sediments are often interpreted in terms of changing source regions with the isotopic composition of individual source regions remaining constant though time. However, recent studies have hinted at seasonal variations in $\varepsilon \mathrm{Nd}$ in river sediments (Viers et al., 2008; Garçon et al., 2013; Lupker et al., 2013), raising the possibility that the $\varepsilon \mathrm{Nd}$ value of sediment exported from individual source regions may not remain constant over time. Thus, although $\varepsilon \mathrm{Nd}$ is a reliable tracer of source, one region may contain multiple end-members, whose relative contributions vary over time.
The source regions to the Arctic Ocean are, in general, relatively poorly characterised in terms of coupled $\varepsilon \mathrm{Nd}$ and ${ }^{87} \mathrm{Sr} /{ }^{86} \mathrm{Sr}$ measurements with only a few samples from the major rivers and shelf sediments (Eisenhauer et al., 1999; Hillaire-Marcel et al., 2013). Svalbard (Fig. 1) is particularly important to characterise owing to its location by the Fram Strait, which is the site of deep water formation essential to the functioning of the global thermohaline circulation, and has therefore been the target of studies seeking to understand the formation of the Atlantic-Arctic gateway (Jakobsson et al., 2007). However, there is neither ${ }^{87} \mathrm{Sr} /{ }^{86} \mathrm{Sr}$ nor $\varepsilon \mathrm{Nd}$ data on river sediments from Svalbard. Previous studies (Tütken et al., 2002; Maccali et al., 2013) have taken the bedrock data of granitoids from Ny Friesland in the north-east of Spitsbergen (the largest island in the Svalbard archipelago, Fig. 2, Johansson et al., 1995; Johansson and Gee, 1999) to represent the Svalbard source region. Svalbard has a wide range of rocks from different ages and in this study we characterise sediments from two catchments located in the Paleogene Central Basin, which comprises $8 \%$ of the land area of Svalbard, and from which no prior $\mathrm{Sr}-$ $\mathrm{Nd}$ measurements exist. Being relatively sparsely glaciated and more easily eroded, these sedimentary formations could constitute an important sediment source from Svalbard. The studied catchments have nominally identical lithology but one is glaciated, allowing us to examine the effect of glaciation on stream suspended sediment composition. As clay minerals are the main constituent of the rocks in the study area, we combine the geochemical data $\left(\varepsilon \mathrm{Nd}\right.$ and $\left.{ }^{87} \mathrm{Sr} /{ }^{86} \mathrm{Sr}\right)$ with clay mineralogy in order to identify the factors influencing the unexpectedly large variation in radiogenic isotope compositions observed in the catchment sediments.

\section{Field site}

Svalbard is located in the Arctic Ocean (Fig. 1) and has an Arctic climate. In 2012 (the year samples were collected) the mean temperature was $-2.0^{\circ} \mathrm{C}$ and precipitation was $268 \mathrm{~mm}$, as recorded at Longyearbyen Airport (Nordli et al., 2012). Permafrost is continuous throughout the islands (Humlum et al., 2003). Two catchments were studied which are situated adjacent to each other approximately $5 \mathrm{~km}$ south of Longyearbyen in central Svalbard (Fig. 2a).

The first catchment is a permafrost-affected valley called Fardalen (Fig. 2c) which is likely to have been unglaciated for at least the last $10 \mathrm{kyr}$ (Svendsen and Mangerud, 1997). The catchment area is $3.4 \mathrm{~km}^{2}$ and ranges in elevation from 250 to $1025 \mathrm{~m}$ a.s.l. The second catchment contains a glacier called Dryadbreen and "Dryadbreen" will be used hereafter to refer to the whole catchment and not just the glacier. Between 1936 and 2006 the area of the glacier decreased from 2.59 to $0.91 \mathrm{~km}^{2}$ leaving large terminal and lateral ice-cored moraines and a sandur in front of the glacier 


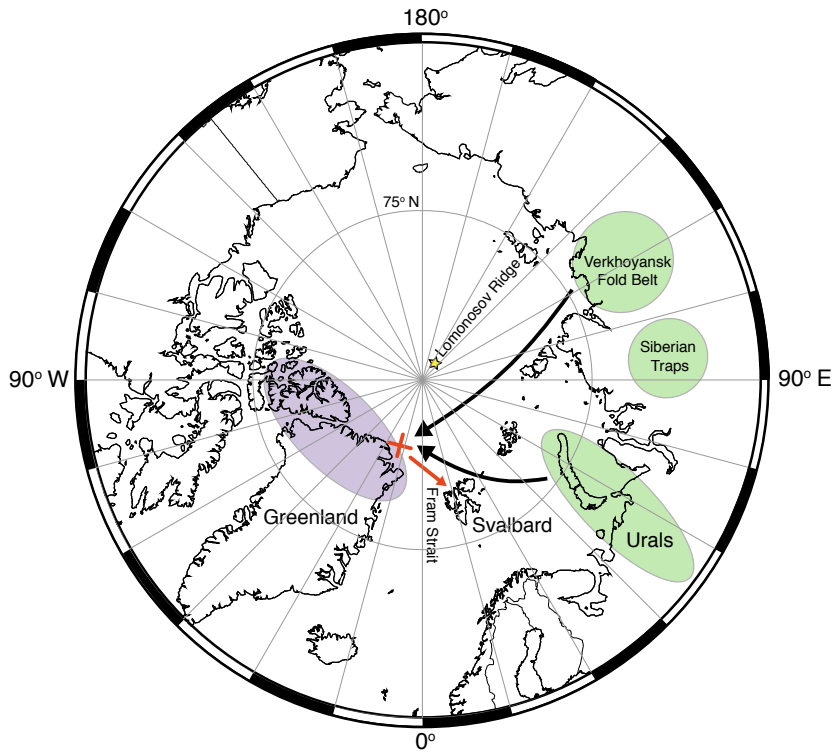

Figure 1. Overview of the circum-Arctic region. The red cross indicates the position of Svalbard during the Paleogene (Jones et al., 2016). The purple shaded area indicates the western shield source whilst the green shaded areas indicate potential basaltic source regions in the east. The yellow star indicates the location of the Gleason et al. (2009) study to recover Eocene seawater compositions referred to in the text.

(Ziaja and Pipała, 2007). The catchment area is $4.8 \mathrm{~km}^{2}$ and ranges in elevation from 250 to $1031 \mathrm{~m}$ a.s.l.

\section{Geological background}

The two studied catchments are situated in the Paleogene sedimentary Central Basin of Svalbard (Fig. 2a). The sedimentary formations exposed in the catchments are from the Van Mijenfjorden group which is Paleocene to Eocene in age (66-33.9 Ma) and contains sandstones, siltstones and shale (Fig. 2b, Major et al., 2000). The formations exposed in the two catchments have been relatively well studied on account of the fact they cover the Paleocene-Eocene Thermal Maximum (PETM) and formed as a consequence of sedimentation which commenced upon the separation of Greenland from Eurasia (e.g. Helland-Hansen, 1990; Müller and Spielhagen, 1990; Cui et al., 2011; Dypvik et al., 2011; Elling et al., 2016; Jones et al., 2016).

The Central Basin sediments are divided into six formations (Major et al., 2000) which were deposited in a series of transgressive-regressive cycles. The youngest four are exposed in the studied catchments. It is thought that the source for the oldest sediments (mid-Paleocene to early Eocene) was from the east (Carboniferous to Jurassic Siberian basalts, Helland-Hansen, 1990), but this changed to the west (Proterozoic Greenlandic/Canadian High Arctic Shield) during early to mid-Eocene with the erosion of the uplifted West (a)

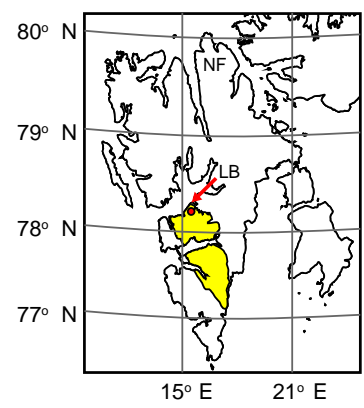

(b) $\mathrm{sw}$
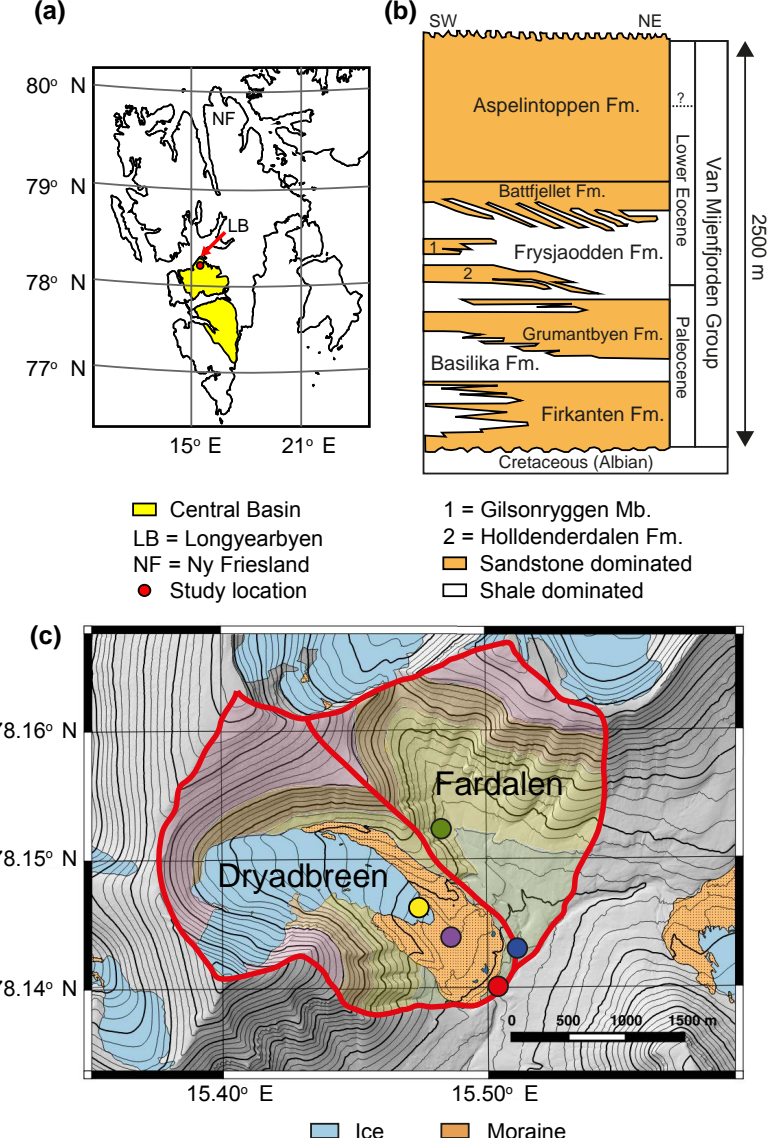

Van Mijenfjorden Group (Paleocene-Eocene)

$\square$ Aspelintoppen Formation: sandstone, siltstone and shale, with thin coal seams $\square$ Battfjellet Formation: sandstone, subordinate siltstone and shale

$\square$ Frysjaodden Formation: dark shale and siltstone, subordinate sandstone $\square$ Grumantbyen Formation: sandstone including shale

Figure 2. (a) Map of Svalbard indicating the extent of the Paleogene Central Basin. The location of the study area in relation to Longyearbyen is also indicated. (b) The stratigraphy of the Van Mijenfjorden Group adapted from Cui et al. (2011). The catchments are located at the north-east side. (c) Topographic map of the sediment sampling locations with the geology of the catchments superimposed. Glaciers and their moraines are shown in blue and orange respectively and contours are displayed at $50 \mathrm{~m}$ intervals. The solid red lines demarcate the catchment boundaries. Dryadbreen is on the left and Fardalen on the right. The coloured circles indicate where samples referred to in Table 1 were collected: R01 and G (green circle); supraglacial stream suspended sediment sample, R03, R04 and D (yellow); Fardalen stream suspended sediment sample and L (blue); Dryadbreen stream suspended sediment sample and $\mathrm{O}$ (red); R02 (purple). Other rock and sediment samples referred to in Table 2 were collected at various locations within the two catchments. Geological information is taken from (Major et al., 2000) and the topographic information is based on GIS data from the Norwegian Polar Institute. 
Spitsbergen fold-and-thrust belt whose formation is linked to rifting of the North Atlantic and the separation of Svalbard from Greenland.

The oldest formation exposed in the studied catchments is the Grumantbyen Formation (Fig. 2b), comprising shallow marine sandstones. The Grumantbyen sediments are part of a regressive trend with sediment derived from the east and possibly the north (Helland-Hansen, 1990). The youngest three formations comprise a regressive sequence with (from oldest to youngest) the Frysjaodden Formation comprising finegrained shales deposited offshore in an open basin; Battfjellet Formation comprising shallow marine sandstone; and Aspelintoppen comprising continental deposits (HellandHansen, 1990; Müller and Spielhagen, 1990). The mountain belt is thought to have eroded rapidly (Cui et al., 2011) based on the immaturity of the sandstones (Helland-Hansen, 1990). Detection of pre-Caledonian metamorphic detritus indicates that the mountain belt was eroded down into the basement rocks (Helland-Hansen, 1990). The PETM boundary is near the base of the Frysjaodden Formation (Charles et al., 2011).

\section{Methods}

A selection of 18 representative solid samples, including sedimentary rocks, bedload sediments and glacial sediment, were sampled from both catchments. The sedimentary rock samples were first crushed (jaw crusher) and were subsequently ground to fine powders (rotary disc mill and planetary ball mill). For the sediment samples, only the latter step was required. A subset of samples (Fig. 2c) were selected for element and isotopic analysis (Table 1) and they are further described here. For all other samples a brief description is included in Table 2. Samples "G" and "R01" are two separate samples of frost-shattered angular pieces of shale, $1-4 \mathrm{~cm}$ in length collected from the Frysjaodden Formation in the unglaciated Fardalen catchment. Samples "R02" (frost-shattered wacke), "R03" (litharenite), "R04" (shale) and "D" (coarse sediment from glacier surface) were collected from the glaciated Dryadbreen catchment where transport and physical erosion by the glacier has combined rocks from different formations. Additionally, sediment from the stream channels of each catchment were collected (samples "L" and "O"). Stream suspended sediment $(>0.2 \mu \mathrm{m})$ was retrieved from nylon filter papers during water sample collection (Hindshaw et al., 2016) by washing the filter paper with deionised water and then freeze drying the sample. Stream suspended sediment samples were collected from each of the catchment streams on alternate days during June (snow melt) and July/August (summer) 2012, just before their confluence with the main valley stream (Fig. 2c). Part of each sample was treated with $5 \% \mathrm{HCl}$ to remove carbonates. The leachates were not retained. A subset of four samples, one from each season and each catchment were analysed for this study (Table 1). Discharge measurements are only available for summer; the discharge at the time of sample collection for the two summer samples was $0.24 \mathrm{~m} \mathrm{~s}^{-1}$ (Fardalen) and $0.35 \mathrm{~m} \mathrm{~s}^{-1}$ (Dryadbreen) (Hindshaw et al., 2016). Suspended sediment concentrations at the time of sampling are reported in Table 1.

\subsection{Semi-quantitative determination of clay mineral abundances}

A $<2 \mu \mathrm{m}$ size fraction was separated from bulk sediment by repeatedly rinsing and re-suspending the sample in deionised water with sodium phosphate as a dispersal agent, followed by sonication. The $<2 \mu \mathrm{m}$ fraction was separated by centrifugation (Moore and Reynolds, 1997) and was then transferred to a clean glass slide in preparation for XRD using a filter-peel technique to orientate the sample (Moore and Reynolds, 1997). XRD analysis was performed on a PANalytical PW1050 X-ray diffractometer with a Hiltonbrooks DG2 X-ray generator (Co-K $\alpha$ radiation) at the University of St. Andrews. Data were collected between 5 and $40^{\circ}$ with a step size of $0.02^{\circ}$ and a counting time of $3 \mathrm{~s}$ per step. Spectra were collected on air-dried, glycerol-treated, $450^{\circ} \mathrm{C}$ heated and $550{ }^{\circ} \mathrm{C}$ heated samples. The glycerol-treated and $450{ }^{\circ} \mathrm{C}$ spectra were used to obtain semi-quantitative clay mineral abundances using the method outlined in Griffin (1971). This technique uses the peak heights of kaolinite 001 and illite 001 in the $450^{\circ} \mathrm{C}$ spectrum and the peak heights of chlorite 004 , kaolinite 002, kaolinite 001 and illite 001 in the glycerol treated spectrum to give the relative abundances of kaolinite, chlorite, illite (mica) and expandable layer clay minerals (e.g. smectite and mixed-layer minerals containing smectite).

\subsection{Chemical and isotopic composition}

A selection of bulk solid samples and separated clay fractions were analysed for major and trace element chemistry using the following method: approximately $100 \mathrm{mg}$ of material was ashed at $950{ }^{\circ} \mathrm{C}$ for $120 \mathrm{~min}$. The sample was then digested in a mixture of concentrated hydrofluoric and nitric acids and repeatedly dried down and re-dissolved in $6 \mathrm{M} \mathrm{HCl}$. In the final step, the dried down sample was redissolved in $2 \% \mathrm{HNO}_{3}$. Major and trace element concentrations were measured at the University of Cambridge by inductively coupled plasma optical emission spectrometry (ICP-OES, Agilent Technologies 5100) and quadrupole inductively coupled plasma mass spectrometry (Q-ICP-MS, Perkin Elmer 63 Nexion 350D), respectively. Si concentrations were calculated by difference assuming $100 \%$ recovery. The accuracy of the Si concentrations obtained in this way was confirmed by comparison with XRF obtained for four samples (Table A1). The accuracy of the concentration measurements was verified by repeated measurements of seven different USGS rock standards (Tables A3 and A4), including two shale standards (SCo-1 and SGR-1b). The pro- 


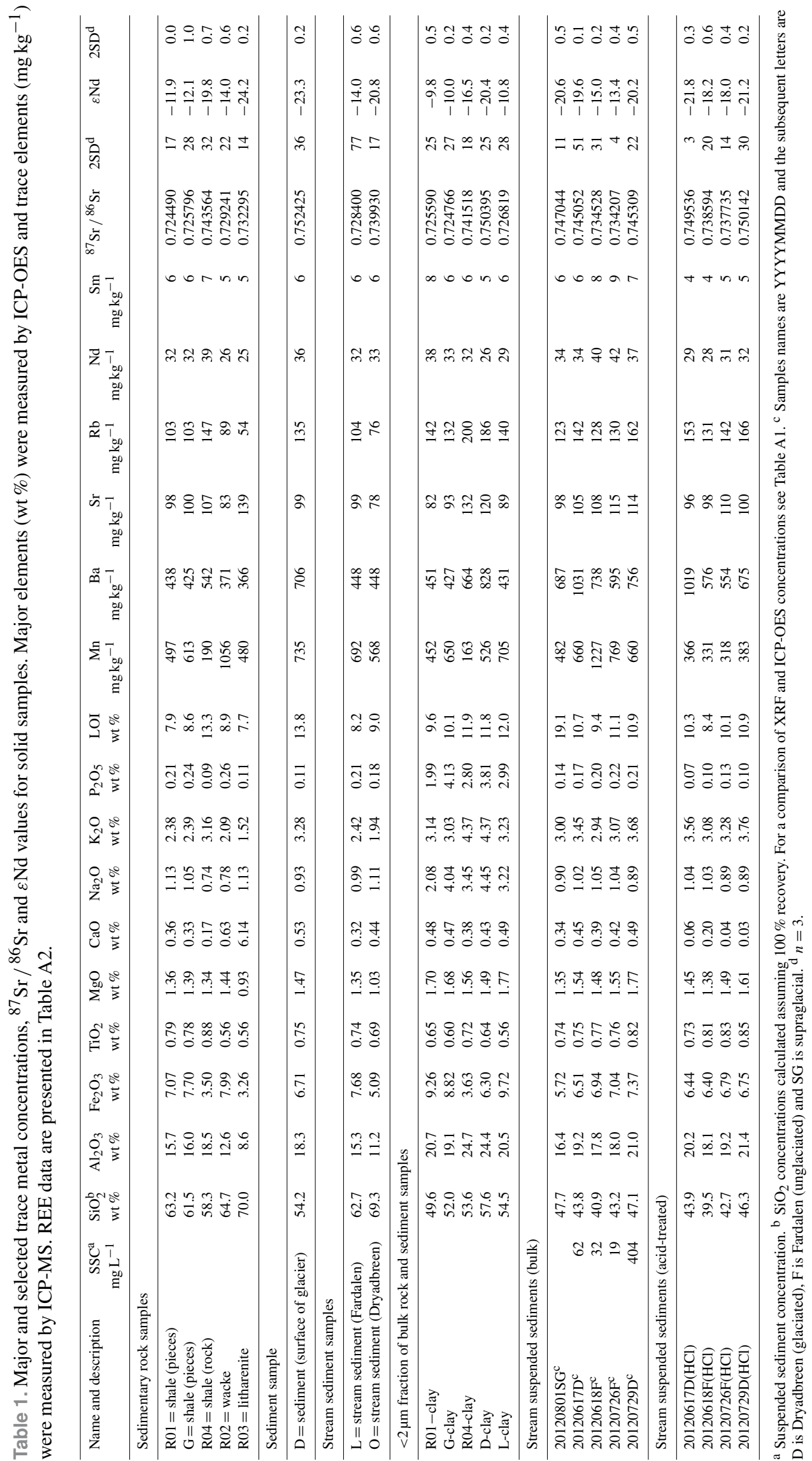


Table 2. Relative proportions of clay minerals as determined from XRD patterns for the solid samples collected in the two catchments. Samples are ordered from highest to lowest relative illite abundance.

\begin{tabular}{|c|c|c|c|c|c|c|}
\hline Sample & Description & Catchment ${ }^{b}$ & Illite (\%) & $\mathrm{I} / \mathrm{S}^{\mathrm{c}}(\%)$ & Kaolinite (\%) & Chlorite (\%) \\
\hline $\mathrm{I}^{\mathrm{a}}$ & Fossil-rich rock & Dr & 82 & 0 & 9 & 9 \\
\hline $\mathrm{D}$ & sediment (Surface of glacier) & Dr & 72 & 12 & 7 & 9 \\
\hline $\mathrm{R}_{03^{\mathrm{a}}}$ & Litharenite & $\mathrm{Dr}$ & 67 & 14 & 8 & 10 \\
\hline $\mathrm{R} 04^{\mathrm{a}}$ & Shale (rock) & $\mathrm{Dr}$ & 59 & 26 & 7 & 7 \\
\hline A & Sandur sediment & $\mathrm{Dr}$ & 52 & 28 & 8 & 12 \\
\hline $\mathrm{F}$ & Moraine sediment & $\operatorname{Dr}$ & 55 & 28 & 8 & 9 \\
\hline $\mathrm{O}$ & Stream sediment & $\operatorname{Dr}$ & 51 & 32 & 8 & 9 \\
\hline $\mathrm{R} 02^{\mathrm{a}}$ & Wacke & $\mathrm{Dr}$ & 48 & 33 & 5 & 14 \\
\hline $\mathrm{H}$ & Soil & $\mathrm{F}$ & 49 & 35 & 9 & 7 \\
\hline M & Stream bank sediment & $\mathrm{F}$ & 51 & 37 & 6 & 7 \\
\hline $\mathrm{C}$ & Moraine sediment & $\mathrm{Dr}$ & 44 & 37 & 9 & 10 \\
\hline $\mathrm{E}^{\mathrm{a}}$ & Shale rock & $\mathrm{Dr}$ & 43 & 40 & 8 & 9 \\
\hline $\mathrm{R} 01^{\mathrm{a}}$ & Shale (pieces) & $\mathrm{F}$ & 46 & 40 & 7 & 7 \\
\hline $\mathrm{N}$ & Stream bedload & $\mathrm{F}$ & 46 & 41 & 6 & 7 \\
\hline $\mathrm{L}$ & Stream sediment & $\mathrm{F}$ & 46 & 43 & 5 & 6 \\
\hline $\mathrm{K}$ & Stream sediment & $\mathrm{F}$ & 45 & 43 & 6 & 6 \\
\hline $\mathrm{B}^{\mathrm{a}}$ & Shale (pieces) & $\mathrm{Dr}$ & 38 & 49 & 6 & 7 \\
\hline $\mathrm{G}^{\mathrm{a}}$ & Shale (pieces) & $\mathrm{F}$ & 36 & 50 & 7 & 7 \\
\hline
\end{tabular}

${ }^{\text {a }}$ Sedimentary (often frost-shattered) rock. All other samples are modern sediments. ${ }^{\mathrm{b}}$ Catchment where sample was collected. F is Fardalen, Dr is Dryadbreen. ${ }^{\mathrm{c}} \mathrm{I} / \mathrm{S}$ is an illite-smectite mixed phase mineral.

cedural blanks through the digestion procedure were negligible $(<0.1 \%$ sample) for $\mathrm{Sr}$ and $\mathrm{Nd}$.

Neodymium was separated from the matrix using the method described in Piotrowski et al. (2009). This method uses two columns. The first column contained Eichrom TRUspec resin which separates out REE from the matrix and the second column contains Eichrom LNSpec resin to isolate $\mathrm{Nd}$. The radiogenic neodymium isotopic composition was measured on a $\mathrm{Nu}$ plasma $(\mathrm{Nu}$ Instruments, University of Cambridge) multi-collector inductively coupled plasma mass spectrometer (MC-ICP-MS). Samples were run at $50-75 \mathrm{ppb}$ with an APEX ACM sample introduction system. Samples were run in triplicate (three measurements on different days) with each measurement comprising 30 cycles with $10 \mathrm{~s}$ integration. Samarium interferences were monitored by measuring mass 149 . No interferences were detected and oxides were monitored during tuning to ensure they were well below $0.5 \%$ of the beam size. The exponential law was applied to correct for instrument mass fractionation and all ${ }^{143} \mathrm{Nd} /{ }^{144} \mathrm{Nd}$ ratios were normalised to ${ }^{146} \mathrm{Nd} /{ }^{144} \mathrm{Nd}=0.7219$. Standardsample bracketing was employed in order to correct for the offset with the accepted JNdi-1 value: $0.512060 \pm 0.000024$ (2SD, $n=119$ ) compared with the accepted value of 0.512115 (Tanaka et al., 2000). The USGS shale standard SCo- 1 was measured and the ${ }^{143} \mathrm{Nd} /{ }^{144} \mathrm{Nd}$ value of $0.512086 \pm 0.000029(n=3,2 \mathrm{SD})$ is in agreement with a previously published value of $0.512117 \pm 0.000010$ ( $2 \sigma, n=20$; Krogstad et al., 2004). Neodymium isotope ratios are reported as deviations relative to the chon- dritic uniform reservoir (CHUR, ${ }^{143} \mathrm{Nd} /{ }^{144} \mathrm{Nd}=0.512638$, Jacobsen and Wasserburg, 1980).

Strontium was separated from the matrix using Biorad Micro Bio-Spin columns with Eichrom SrSpec resin (Hindshaw, 2011). The radiogenic strontium isotopic compositions were measured on a Neptune MC-ICP-MS (Thermo, University of Cambridge) and were run at $50 \mathrm{ppb}$ using an APEX sample introduction system. Samples were run in triplicate (three measurements on different days) with each measurement comprising 30 cycles with $8 \mathrm{~s}$ integration. ${ }^{85} \mathrm{Rb}$ was monitored to correct for rubidium interferences on ${ }^{87} \mathrm{Sr}$ and data were additionally corrected for $\mathrm{Kr}$ interferences by measuring ${ }^{83} \mathrm{Kr}$. The exponential law was applied to correct for instrument mass fractionation and all ${ }^{87} \mathrm{Sr} /{ }^{86} \mathrm{Sr}$ ratios were normalised to ${ }^{86} \mathrm{Sr} /{ }^{88} \mathrm{Sr}=0.1194$. Measurements of NBS 987 gave a ${ }^{87} \mathrm{Sr} /{ }^{86} \mathrm{Sr}$ value of $0.710249 \pm 29$ (2SD, $n=27$ ) and the seawater value was $0.709188 \pm 24$ (2SD, $n=9$ ), which is within error of the accepted value of $0.709179 \pm 8(2 \sigma, n=17$, Mokadem et al., 2015).

\section{Results}

The major and trace element concentrations of the solid samples are provided in Table 1. The measured values are typical for shales (Taylor and McLennan, 1985) and the rare earth element (REE) chondrite normalised element profile of these samples closely follows that of the Post Archaean Australian Shale (PAAS, Table A2). Strontium and neodymium concentrations vary from 78 to 139 and 25 to 49 ppm, respectively. 

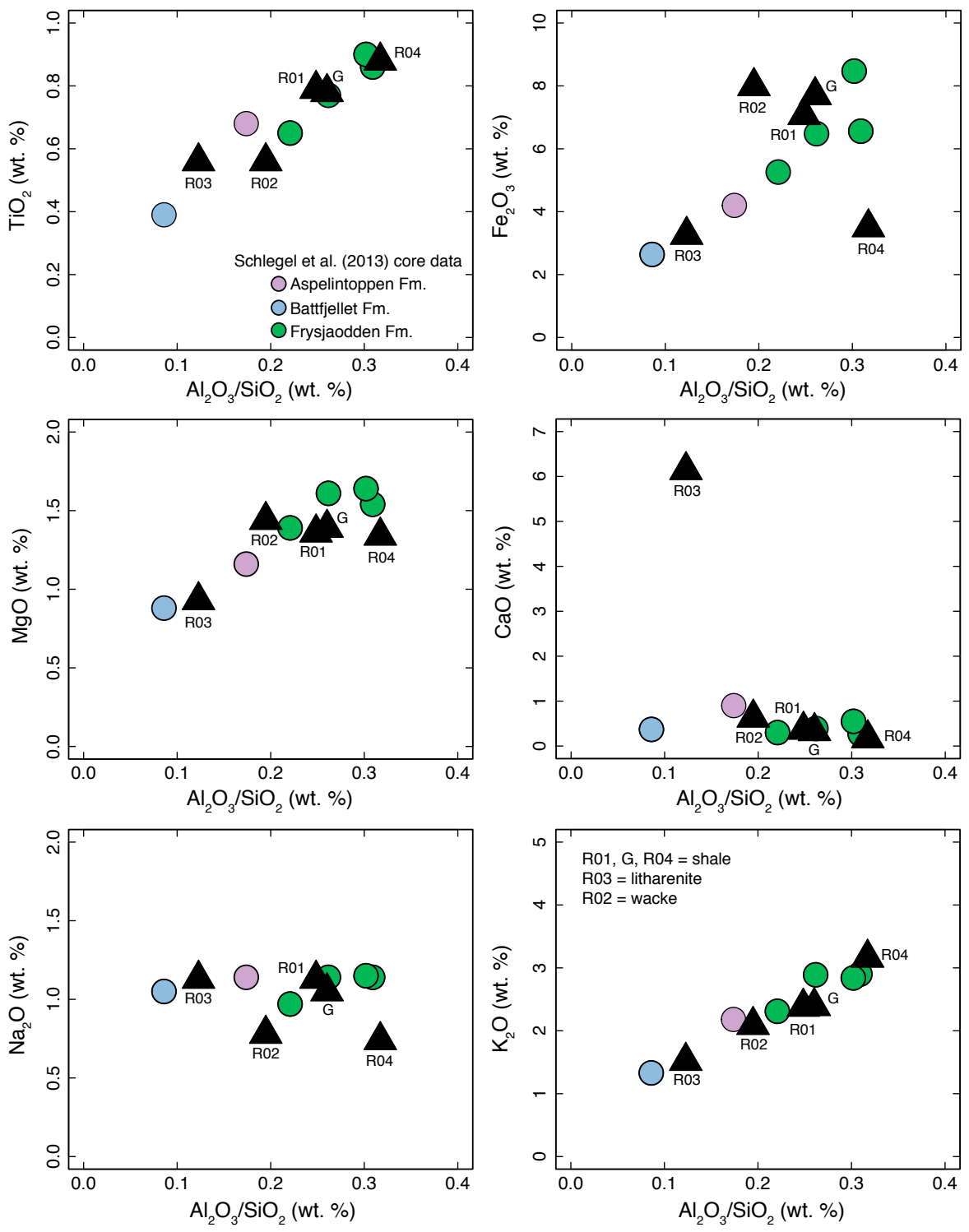

Figure 3. Plots of major elements in the collected rock samples against the $\mathrm{Al}_{2} \mathrm{O}_{3} / \mathrm{SiO}_{2}$ ratio compared with core data (Store Norske Well 11-2003) covering the same formations (Schlegel et al., 2013). Sample R03 contains $10 \%$ carbonate, accounting for the high Ca concentration (Hindshaw et al., 2016).

The two rock samples collected from the Frysjaodden Formation (R01 and G) have very similar major element compositions to core samples from this formation (Fig. 3, Schlegel et al., 2013). The formations in the glaciated catchment were not clearly exposed due to the presence of moraine material. However, the core sample from the Aspelintoppen Formation is classified as a litharenite (Fig. 4) and as sample R03 is a litharenite and has similar major element chemistry (Fig. 3), we infer that this sample is also derived from the Aspelintoppen Formation. Sample R02 plots close to the wacke-shale boundary in Fig. 4 and in terms of major element chemistry it plots on the edge of the area defined by the Frysjaodden sam- ples (Fig. 3). We therefore infer that this sample originated close to the boundary between the Frysjaodden and Battfjellet formations. Sample R04 is classified as a shale (Fig. 4) but its major element composition is distinct from the Frysjaodden Formation samples, in particular for $\mathrm{Fe}_{2} \mathrm{O}_{3}$ (Fig. 3). Given that this sample was collected on the surface of the glacier, it is likely that it is a shale derived from either the Battfjellet or Aspelintoppen Formation. These assignments are corroborated by the clay mineralogy (see below).

There is a large range in both the strontium and neodymium isotopic compositions of the bulk solid samples: ${ }^{87} \mathrm{Sr} /{ }^{86} \mathrm{Sr}=0.72449$ to 0.75243 and $\varepsilon \mathrm{Nd}=-24.2$ to -11.9 


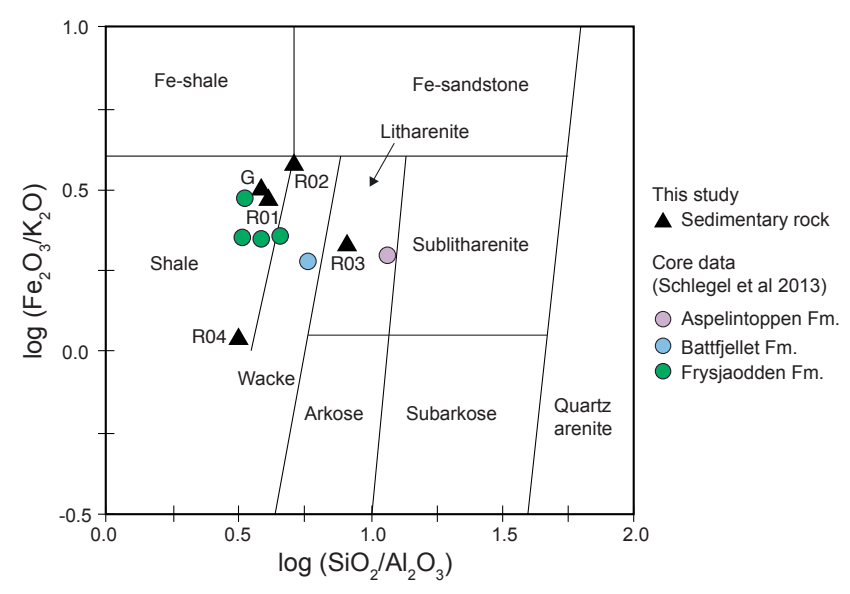

Figure 4. Herron classification (Herron, 1988) of the sedimentary rock samples collected in this study and from the core analysed by Schlegel et al. (2013). Samples G and R01 were collected in the unglaciated catchment (Fardalen) directly from the Frysjaodden Formation. Samples R03, R02 and R04 were collected in the glaciated catchment (Dryadbreen) but could not be linked to a specific formation in the field due to the heterogeneous nature of moraine material. Based on this classification and the major element chemistry (Fig. 3) we infer that R03 was derived from the Aspelintoppen Formation and R02 close to the Battfjellet/Frysjaodden boundary. Sample R04 is classified as a shale but has a markedly different iron content (Fig. 3) to the shale samples from the Frysjaodden Formation (R01, G). Based on its sampled location on the surface of the glacier we infer that it is a shale from either the Battfjellet or Aspelintoppen formations (Fig. 2c).

(Table 1). Radiogenic Sr and Nd values are inversely correlated (Fig. 5) and in general, samples collected from the unglaciated Fardalen catchment, e.g. R01 and G have higher ${ }^{87} \mathrm{Sr} /{ }^{86} \mathrm{Sr}$ and lower $\varepsilon \mathrm{Nd}$ values than those samples collected in the glaciated Dryadbreen catchment, e.g. D and O (Table 1).

The clay-sized fraction forms a parallel array to the bulk rock samples in $\varepsilon \mathrm{Nd}^{8}{ }^{87} \mathrm{Sr} /{ }^{86} \mathrm{Sr}$ space (Fig. 5), with the claysized samples having higher $\varepsilon \mathrm{Nd}$ and lower ${ }^{87} \mathrm{Sr} /{ }^{86} \mathrm{Sr}$ values (except for R01). The $\varepsilon \mathrm{Nd}$ values of clay fractions were 2.1 to 3.2 epsilon units higher than the corresponding bulk sample and ${ }^{87} \mathrm{Sr} /{ }^{86} \mathrm{Sr}$ values were 1030 to $2030 \mathrm{ppm}$ lower in the clay compared to the bulk, apart from sample R01 where the clay was $1100 \mathrm{ppm}$ higher in the clay than in the bulk. Rubidium, strontium, neodymium and samarium concentrations in clay samples are comparable to, or higher than, bulk values (Table 1). Given that clay minerals constitute $>88 \%$ of the non-quartz minerals in these samples (Hindshaw et al., 2016), clays are the main host of these elements. In a compilation of river sediments from all over the world, the clay fraction $\varepsilon \mathrm{Nd}$ value was observed to be greater than the silt-sized fraction by an average of 0.8 epsilon units (Bayon et al., 2015). Fine sediments (as measured by $\mathrm{Al} / \mathrm{Si}$ ratio) from the Mackenzie River have also been observed

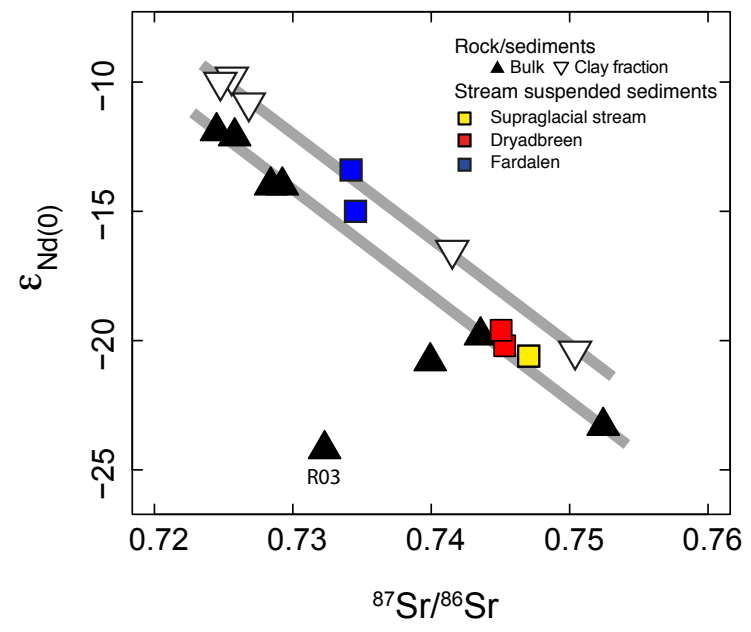

Figure 5. A plot of ${ }^{87} \mathrm{Sr} /{ }^{86} \mathrm{Sr}$ vs. $\varepsilon \mathrm{Nd}$. The grey lines highlight the parallel trends of the bulk and the clay-sized fraction data. Sample R03 is a litharenite whereas the other samples are predominantly shale (Table 1).

to have higher values than coarser sediments (Vonk et al., 2015). The offset in $\varepsilon N d$ between fine and coarse fractions has been interpreted to reflect the preferential transport of basalt and volcanics in the fine fraction (McLennan et al., 1989; Garçon and Chauvel, 2014; Bayon et al., 2015). A volcanic signal is typically only observed in the first sedimentary cycle, due to the rapid chemical weathering of volcanic particles (McLennan et al., 1989) and therefore, if volcanics are present, they must have been deposited at the same time as the Central Basin sediments. Potential volcanic sources for this period could be the volcanic provinces of North Greenland and Ellesmere Island (58-61 Ma, Jones et al., 2016).

The residues of suspended sediments (collected on $0.2 \mu \mathrm{m}$ filter paper) after treatment with $5 \% \mathrm{HCl}$ had higher ${ }^{87} \mathrm{Sr} /{ }^{86} \mathrm{Sr}(3528-4832 \mathrm{ppm})$ and lower $\varepsilon \mathrm{Nd}$ values (1.0 to 4.6 epsilon units) than the corresponding unleached sediment.

\section{Semi-quantitative clay abundance}

Illite, chlorite and kaolinite were present in all the samples analysed. In addition, the presence of an expandable layer clay mineral is also evident in the collapse of the XRD signal around $12.7 \AA\left(8^{\circ} 2 \theta\right.$ Co radiation) between the air-dried and glycerol-treated spectra (Fig. 6). Additionally, the asymmetry of the illite 001 peak (Fig. 6) suggests that this expandable layer clay mineral is an illite-smectite mixed-layer phase (Moore and Reynolds, 1997) and this is in agreement with the interpretation by Dypvik et al. (2011) of XRD spectra from core samples from the same formations exposed in the studied catchments. This mixed layer expandable phase will be referred to as "I/S" in the following discussion. The 

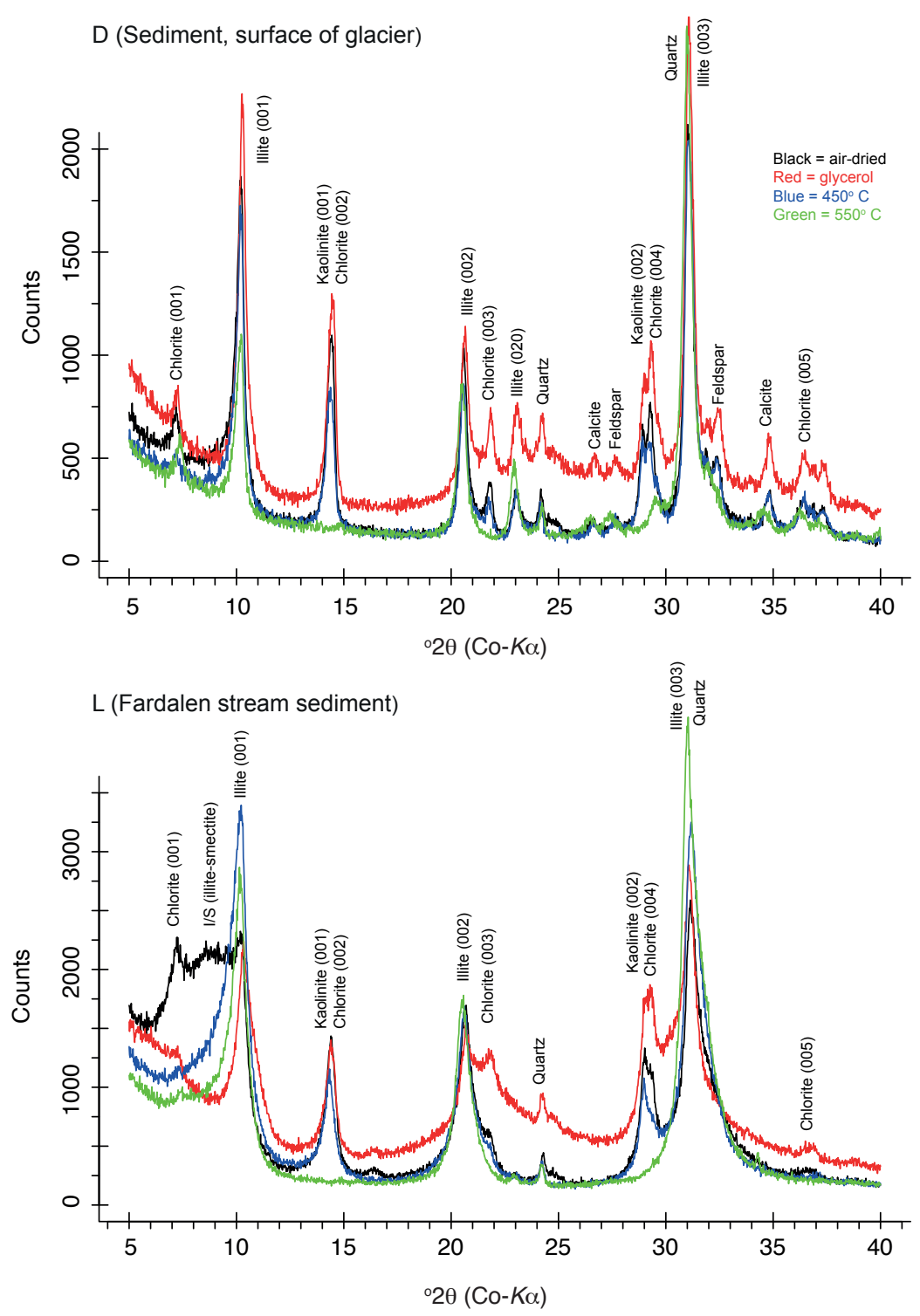

Figure 6. XRD patterns from two different samples: one with a high relative illite abundance (D) and one with low relative illite abundance and the clear presence of an expandable clay, likely an illite-smectite (I/S) mixed phase mineral (L).

relative proportions of illite, chlorite, kaolinite and I/S are given in Table 2.

The solid samples collected from the glaciated Dryadbreen catchment tend to have higher illite abundances and lower I/S abundances than those samples collected from the unglaciated Fardalen catchment (Table 2). For all samples, there is an inverse relationship between the relative abundances of I/S and illite (Fig. 7b). The relative abundances of kaolinite and chlorite were similar in both catchments (Table 2). We are not able to distinguish between authigenic and detrital clay minerals.

The clay-sized fraction of the sedimentary rock samples from the Frysjaodden Formation (R01, G) have a lower rela- tive proportion of illite than the samples inferred to be derived from the Battfjellet (R02) and Aspelintoppen (R03) formations (Fig. 7). This is in agreement with the decrease in the relative proportion of illite observed in the clay-sized fraction of core samples from the Aspelintoppen Formation $(64 \%)$ to the Frysjaodden Formation $(51 \%)$ (Schlegel et al., 2013). Samples with a high relative proportion of illite had high ${ }^{87} \mathrm{Sr} /{ }^{86} \mathrm{Sr}$ and low $\varepsilon \mathrm{Nd}$ values compared to those with a low relative proportion (Fig. 7c,d). 

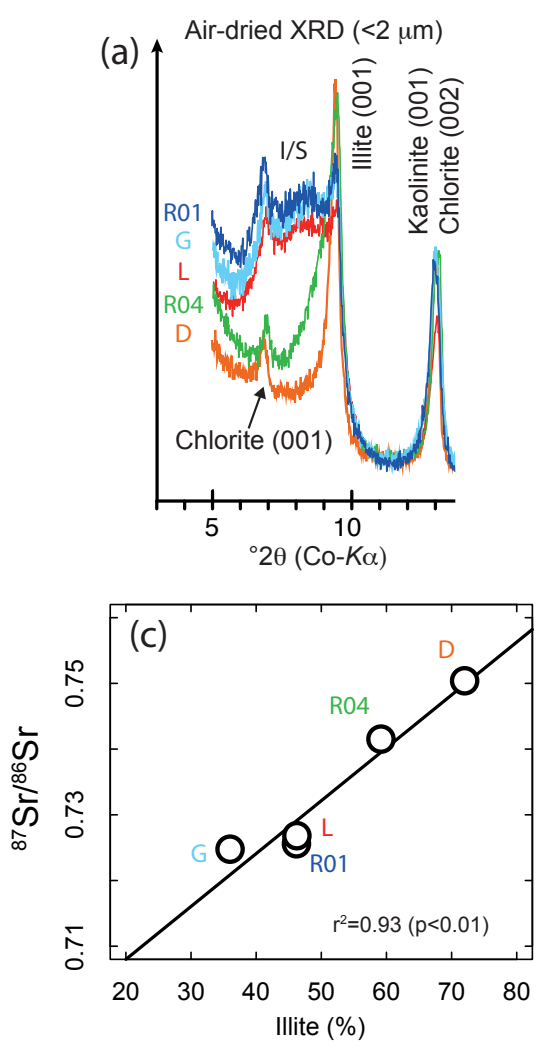
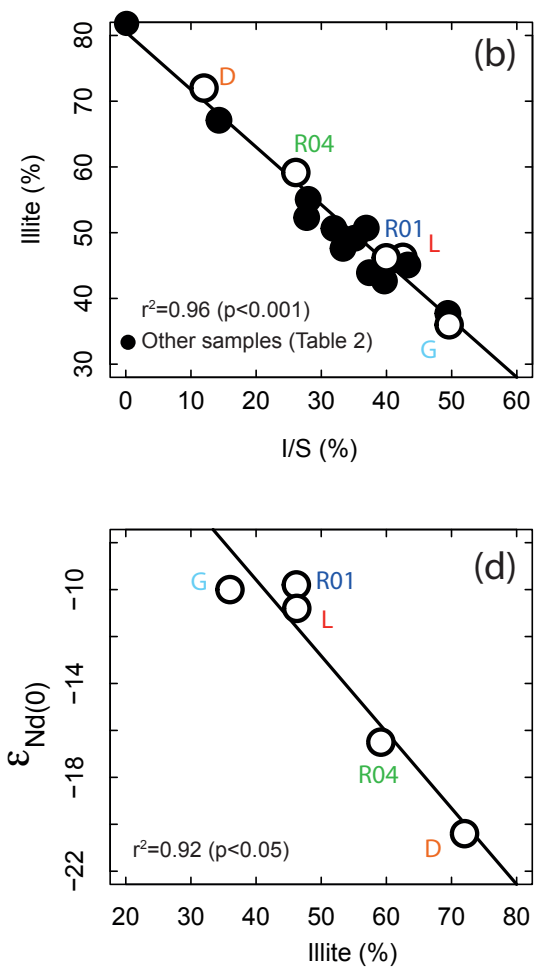

Figure 7. (a) Part of the orientated clay XRD spectrum (air-dried) for five samples. I/S stands for a mixed layer clay containing smectite and illite. Note the decrease in the I/S peak from R01 to D. (b) The relative abundances of illite and I/S in the clay fraction are inversely correlated. (c, d) There is a positive correlation between the relative abundance of illite and the radiogenic strontium isotope ratio in the clay fraction and an inverse correlation with the radiogenic neodymium isotope ratio.

\section{Discussion}

The variation in clay mineralogy, ${ }^{87} \mathrm{Sr} /{ }^{86} \mathrm{Sr}$ and $\varepsilon \mathrm{Nd}$ could be caused by three scenarios: mixing between two or more sediment sources, sedimentary processes (either modern or in the Eocene), or a combination of source and process effects.

\subsection{Sediment sources}

The linear trend between ${ }^{87} \mathrm{Sr} /{ }^{86} \mathrm{Sr}$ and $\varepsilon \mathrm{Nd}$ is suggestive both of a common regional process affecting both isotope systems (Goldstein and Jacobsen, 1988) and of mixing between two end-members. The sediments deposited in the Central Basin during the Eocene were themselves derived from Mesozoic sediments. Based on zircon dating, it is thought that during the Mesozoic, the sediment source to Svalbard alternated between an older (Proterozoic) western component comprised of re-worked sediments from Greenland and Canada and a younger (CarboniferousJurassic) eastern component from Siberian fold-and-thrust belts (Fig. 1, Bue and Andresen, 2014; Elling et al., 2016; Petersen et al., 2016). The erosion of the Siberian Traps which formed within the same time period (Permian to Triassic) would also have contributed sediment to the ocean. We will refer to these two sources as "East" and "West".

The eastern source (Fig. 1, Lightfoot et al., 1993; Wooden et al., 1993; Spadea and D'Antonio, 2006) is relatively welldefined since the samples are essentially mono-lithologic (basaltic) and were deposited over a relatively short time period. Based on zircon dating, both the Uralides and the Verkhoyansk fold-and-thrust belt (Fig. 1) have been identified as potential sources to Svalbard Mesozoic sediments and the Paleocene Basilika and Firkanten formations (Fig. 2b, both underlie the Grumantbyen Formation) (Bue and Andresen, 2014; Elling et al., 2016; Petersen et al., 2016). The western end-member is much harder to characterise as it consists of Precambrian rocks which have undergone extensive metamorphism. An end-member with $\varepsilon N d$ values lower than -23.3 is required (D, Table 1$)$ and therefore only data from western Greenland is considered (Fig. 1). The east coast was affected by the Caledonian orogeny (Henriksen, 1999) and later by the rifting of the North Atlantic (Bernstein et al., 1998) and therefore has higher (younger) $\varepsilon \mathrm{Nd}$ values (Jeandel et al., 2007). 
The range in ${ }^{87} \mathrm{Sr} /{ }^{86} \mathrm{Sr}$ and $\varepsilon \mathrm{Nd}$ from literature data of Archaean rocks from western and northern Greenland (Jacobsen, 1988; Collerson et al., 1989; Weis et al., 1997; Kalsbeek and Frei, 2006; Friend et al., 2009) is 0.70153 to 2.33356 and -56 to -2.75 . By changing the $\mathrm{Sr} / \mathrm{Nd}$ mass ratio of these two end-members, mixing lines can be drawn which encompass all the data, with the majority of points falling on a mixing line with an $r$ value of 1 (i.e. the $\mathrm{Sr} / \mathrm{Nd}$ mass ratio of both end-members is the same, Fig. 8). The variation of ${ }^{87} \mathrm{Sr} /{ }^{86} \mathrm{Sr}$ and $\varepsilon \mathrm{Nd}$ in the clay-sized fraction forms a parallel trend to the bulk samples and can be explained by the same two end-members, but with a lower $r$ value (Fig. 8). Variation in the $r$ value between the bulk and the clay-sized fraction is to be expected given their different mineralogical compositions.

The variation in clay mineralogy (Fig. 7) can be explained by the different lithological sources of the two end-members (Fig. 8). Basalt typically weathers to smectite group minerals (e.g. Curtin and Smillie, 1981; Parra et al., 1985) and modern sediments originating from Siberia (basaltic) are enriched in smectite (Nürnberg et al., 1994; Wahsner et al., 1999). Any volcanic particles present will also tend to weather to smectite (Bayon et al., 2015). The western source is dominated by granitic rocks where the mica and K-feldspar typically weather to illite and kaolinite, respectively (Essington, 2004). Illite has high $\mathrm{Rb} / \mathrm{Sr}$ ratios and detrital illite is resistant to weathering. As the western source is old, this results in high ${ }^{87} \mathrm{Sr} /{ }^{86} \mathrm{Sr}$ and low $\varepsilon \mathrm{Nd}$ values. By contrast, the younger eastern source will have lower ${ }^{87} \mathrm{Sr} /{ }^{86} \mathrm{Sr}$ and higher $\varepsilon \mathrm{Nd}$ values (Fig. 10). The lower ${ }^{87} \mathrm{Sr} /{ }^{86} \mathrm{Sr}$ and higher $\varepsilon \mathrm{Nd}$ values of the sedimentary rocks from the Frysjaodden Formation (G, R01) compared to those of the Battfjellet Formation (R04, Table 1) implies that the Frysjaodden Formation contains a greater proportion of the eastern end-member (Fig. 8). Indeed, zircon dating of samples from the Battfjellet Formation was consistent with a western, Greenland/Canadian Shield source, with an almost complete lack of Uralide aged grains (Petersen et al., 2016). The distinct differences between the two end-member sources leads to the observed correlations between clay mineralogy, ${ }^{87} \mathrm{Sr} /{ }^{86} \mathrm{Sr}$ and $\varepsilon \mathrm{Nd}$ values (Figs. 7 and 10).

Mixing of two sediment sources can explain the difference between the stream suspended sediments collected in the two catchments (Fig. 5). Stream suspended sediments from the glaciated Dryadbreen catchment have lower $\varepsilon \mathrm{Nd}$, higher ${ }^{87} \mathrm{Sr} /{ }^{86} \mathrm{Sr}$ values and a greater relative proportion of illite, compared to those from the unglaciated Fardalen catchment. These observations can be readily accounted for if the stream suspended sediments from Fardalen receive a greater relative contribution from the Frysjaodden Formation (enriched in the eastern end-member) than stream suspended sediments from Dryadbreen (Figs. 2 and 10). The lower relative contribution of the Frysjaodden Formation to stream suspended sediments from the glaciated Dryadbreen catchment can be explained by the moraine material being predomi-

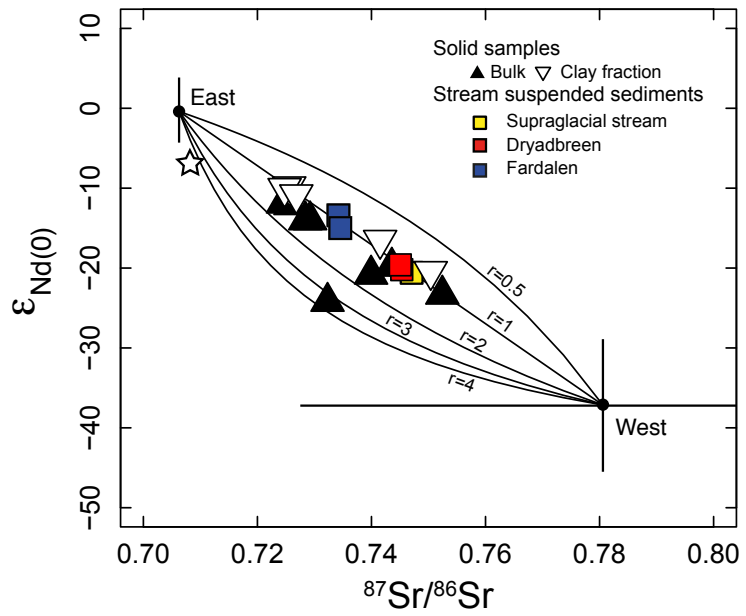

Figure 8. Plot of $\varepsilon \mathrm{Nd}$ vs. ${ }^{87} \mathrm{Sr} /{ }^{86} \mathrm{Sr}$. The two points "East" $\quad\left({ }^{87} \mathrm{Sr} /{ }^{86} \mathrm{Sr}=0.70626, \quad \varepsilon \mathrm{Nd}=-0.4\right) \quad$ and "West" $\left({ }^{87} \mathrm{Sr} /{ }^{86} \mathrm{Sr}=0.78059, \varepsilon \mathrm{Nd}=-37.1\right)$ are averages of the interquartile range of literature data and the error bars indicate the interquartile range (for the "East" source the error in ${ }^{87} \mathrm{Sr} /{ }^{86} \mathrm{Sr}$ is too small to see). "East" data $(n=99)$ : Siberian Traps (Lightfoot et al., 1993; Wooden et al., 1993) and Uralides (Spadea and D'Antonio, 2006). "West" data $(n=65)$ : Archaean rocks (predominantly gneisses, Jacobsen, 1988; Collerson et al., 1989; Kalsbeek and Frei, 2006; Friend et al., 2009), basal ice particles from GISP 2 and GRIP and granite bedrock samples from GISP 2 (Weis et al., 1997). The " $r$ " values are the $\mathrm{Sr} / \mathrm{Nd}$ ratio of the "East" source divided by the $\mathrm{Sr} / \mathrm{Nd}$ ratio of the "West" source. The star indicates the isotopic composition of Eocene seawater (Gleason et al., 2009, see text for details).

nantly derived from sedimentary rocks once located in the upper reaches of the catchment (Aspelintoppen Formation), and the modern day sandur plain, containing the products of this physical erosion, essentially burying the lower Frysjaodden Formation. Changes in erosion caused by glaciation, which conveys sediment from the head to the toe of the glacier, could therefore influence the $\mathrm{Sr}$ and $\mathrm{Nd}$ isotopic of sediments exported to the ocean (von Blanckenburg and Nägler, 2001).

\subsection{Sedimentary processes}

\subsubsection{Grain-size sorting}

Sediments are sorted as a function of particle size as they travel through the water, such that coarser particles (typically primary minerals such as feldspar and quartz) will settle faster than finer particles (clay minerals). A size-sorting effect is observed in the difference between the ${ }^{87} \mathrm{Sr} /{ }^{86} \mathrm{Sr}$ and $\varepsilon \mathrm{Nd}$ values of the bulk and the clay-sized $(<2 \mu \mathrm{m})$ fraction. This effect is observed at a global scale and is interpreted to reflect the preferential transport of volcanics and basalt in the fine fraction (Bayon et al., 2015). However, mineral sorting between a clay-sized fraction and a coarser fraction cannot 
account for the overall trend in the bulk samples (Fig. 5) as the clay minerals plot on a parallel array to the bulk samples (Fig. 5) indicating that the clay-sized fraction is not an end-member of the bulk sample trend. The offset between the clay-sized fraction and bulk is consistent with the clay-sized fraction being enriched in authigenic phases with higher $\varepsilon \mathrm{Nd}$ and lower ${ }^{87} \mathrm{Sr} /{ }^{86} \mathrm{Sr}$ compared to the bulk which is more likely to contain detrital minerals with a larger grain size.

Grain-size sorting could occur within the clay-sized fraction as illite will settle faster than smectite in the marine environment (Sionneau et al., 2008). The Frysjaodden Formation, being furthest away from shore, could become enriched in smectite-enriched particles derived from the basaltic eastern end-member whereas the Aspelintoppen Formation, deposited in a near-shore environment, could become enriched in relatively coarser illite-enriched particles derived from the granitic western end-member. As clays form $>88 \%$ of the non-quartz mineral fraction of the bulk (excluding R03 which does not plot on the main trend, Fig. 5, Hindshaw et al., 2016), the trends observed between illite, smectite (I/S) and the radiogenic isotope compositions (Fig. 7) should be reflected in the bulk samples (Fig. 5).

\subsubsection{Preferential leaching of a labile phase}

There are examples from previous studies where chemical weathering has been identified as the cause of an inverse correlation between the relative proportions of illite and smectite (Fig. 7b, e.g. Setti et al., 2004). However, whilst modern day weathering processes can induce large variations in ${ }^{87} \mathrm{Sr} /{ }^{86} \mathrm{Sr}$ primarily as a result of large inter-mineral variations in the $\mathrm{Rb} / \mathrm{Sr}$ ratio (e.g. Bullen et al., 1997), it is much harder to induce large variations in the $\mathrm{Sm} / \mathrm{Nd}$ ratio of minerals and this ratio is often assumed to remain constant once a rock has been formed (e.g. McCulloch and Wasserburg, 1978). Preferential release of minerals with different $\mathrm{Sm} / \mathrm{Nd}$ ratios during chemical weathering has been implicated in the generation of small $\varepsilon \mathrm{Nd}$ offsets of around $2 \mathrm{ep}-$ silon units (Rickli et al., 2013) and larger variations in $\varepsilon \mathrm{Nd}$ were observed in a soil profile developed on granitic till in northern Sweden (Öhlander et al., 2000). In the latter study, a 7.7 epsilon unit variation was observed between the E horizon and the humic horizon, which was attributed to the preferential weathering of minerals enriched in $\mathrm{Nd}$ over $\mathrm{Sm}$ (e.g. allanite).

In these catchments there is essentially no soil development due to recent glaciation and at the bulk scale the mineralogy of the rocks is broadly similar (Hindshaw et al., 2016) as are their $\mathrm{Sm} / \mathrm{Nd}$ ratios (Table 1). Additionally, the major element chemistry is very similar to that observed in core samples drilled through the same formations (Fig. 3, Schlegel et al., 2013), confirming that weathering processes since the Paleocene have had little impact on bulk element and, by inference, ${ }^{87} \mathrm{Sr} /{ }^{86} \mathrm{Sr}$ and $\varepsilon \mathrm{Nd}$ values. The geochemical changes observed between formations in the core samples
(Schlegel et al., 2013) were attributed to increased chemical weathering during the late Paleocene. In the given time period of this study $(50 \mathrm{Ma})$ preferential weathering of minerals with $\mathrm{Sm} / \mathrm{Nd}$ ratios significantly different from bulk would be required in order to generate the 14 epsilon unit variation in $\varepsilon \mathrm{Nd}$. In order to test this hypothesis, we applied a $5 \% \mathrm{HCl}$ leach to remove easily leached mineral phases.

The chemical and isotopic composition of leached suspended sediment is distinct from bulk suspended sediment (Fig. 9a). From mass balance constraints, this points to the existence of a labile pool containing $\mathrm{Ca}, \mathrm{P}, \mathrm{Mn}$ and $\mathrm{Fe}$, with low ${ }^{87} \mathrm{Sr} /{ }^{86} \mathrm{Sr}$ and high $\varepsilon \mathrm{Nd}$ (Table 1, Fig. 9a). Over $50 \%$ $\mathrm{Ca}$ is leached from the sediments with a $\mathrm{Sr} / \mathrm{Ca}$ mass ratio of 0.002 to 0.007 , consistent with carbonate (Veizer, 1983), which would be expected to dissolve readily in $5 \% \mathrm{HCl}$ (Tessier et al., 1979). A loss of $\mathrm{P}$ is also observed (39-56\%, Table 1) suggesting the dissolution of apatite (containing $\mathrm{Ca}$ and $\mathrm{Sr}$ ), and the decrease in $\mathrm{Fe}$ and Mn concentrations (Table 1) could be indicative of leaching $\mathrm{Fe}-\mathrm{Mn}$ oxyhydroxides. In addition to apatite and carbonate, $\mathrm{Sr}$ could be derived from exchange sites within the clay minerals or adsorbed onto $\mathrm{Fe}-\mathrm{Mn}$ oxyhydroxide surfaces. Further, the leaching procedure applied in this study is relatively aggressive and could have dissolved part of the clay mineral structure (Chester and Hughes, 1967).

REE (rare earth element) patterns in leachates are commonly used to identify which mineral phases have been leached (e.g. Haley et al., 2004). The residual phase is depleted in MREE (middle REE) (Fig. 9b), implying the leachate is MREE enriched. A MREE enrichment is consistent with diagenetic apatite and $\mathrm{Fe} / \mathrm{Mn}$ oxyhydroxides (Ohr et al., 1994; Tricca et al., 1999; Johannesson and Zhou, 1999; Su et al., 2017) and inconsistent with a carbonate phase, which is typically HREE (high REE) enriched (Byrne and Kim, 1990; Millero, 1992; Byrne and Sholkovitz, 1996), suggesting that $\mathrm{Nd}$ in the leachate is derived from the former phases. Volcanic ash also has a MREE enriched REE pattern (Tepe and Bau, 2014) and would have high $\varepsilon N d$ and low ${ }^{87} \mathrm{Sr} /{ }^{86} \mathrm{Sr}$. However, the amount of a volcanic component is expected to be minor in the studied sediments as the volcanic ash component of particulates readily leaches upon contact with seawater (Pearce et al., 2013; Wilson et al., 2013) and therefore may already have been leached during deposition in the Paleocene-Eocene. Additionally, volcanic ash in these layers has been diagenetically altered to bentonites (Cui et al., 2011; Elling et al., 2016; Jones et al., 2016) which are unlikely to be readily leached.

The shales in the Frysjaodden Formation were deposited in the marine environment. Any authigenic minerals which were formed at that time are likely to have incorporated fluids with the Eocene seawater composition and deep-sea clays are most susceptible to incorporating seawater (Dasch, 1969). Furthermore, smectite is the only clay mineral which forms in significant amounts in seawater (Griffin et al., 1968) and therefore, it is very likely that the deep-sea Frysjaodden For- 

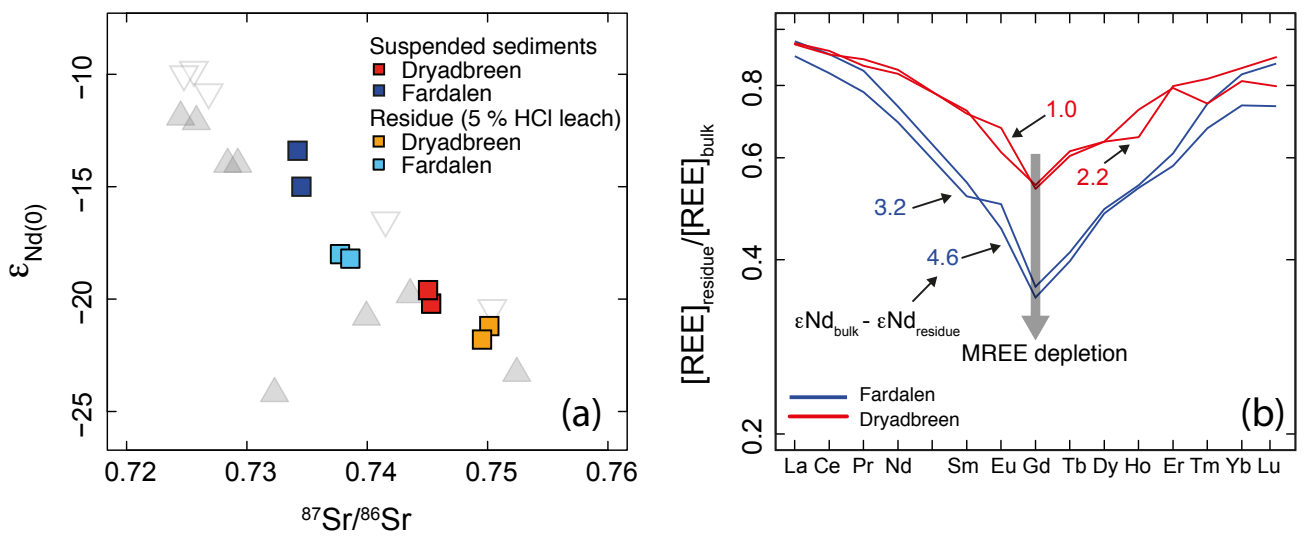

Figure 9. (a) $\varepsilon \mathrm{Nd}$ and ${ }^{87} \mathrm{Sr} /{ }^{86} \mathrm{Sr}$ data for bulk stream suspended sediments and residual stream suspended sediments after leaching with $5 \% \mathrm{HCl}$. The grey symbols in the background are the data from Fig. 5. (b) Rare earth element (REE) abundances of the residue relative to the bulk phase. The greater the depletion in middle REE (MREE), the greater the difference in $\varepsilon \mathrm{Nd}$ between bulk and residual phases and this difference is most pronounced in the unglaciated catchment (Fardalen) where relative I/S abundances are higher compared to the glaciated catchment (Dryadbreen, Table 2). The residual phases have a lower $\varepsilon$ Nd value compared to the bulk.

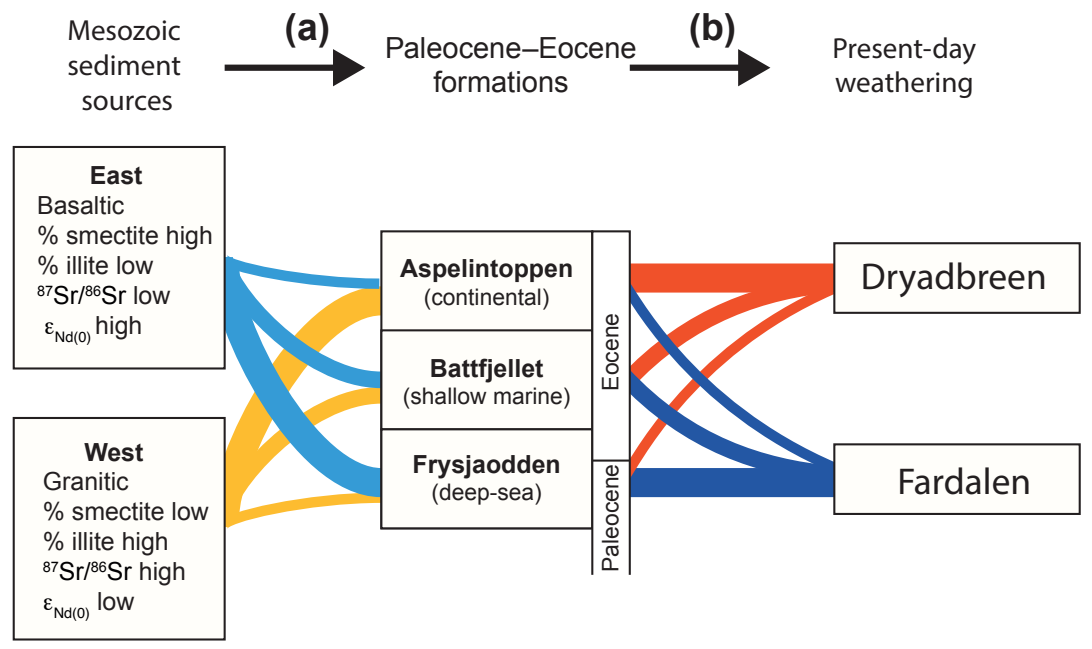

Figure 10. Summary of the processes leading to the variation in clay mineralogy, ${ }^{87} \mathrm{Sr} /{ }^{86} \mathrm{Sr}$ and $\varepsilon$ Nd observed in the two studied catchments. The thickness of the lines gives an indication of the relative contribution of Mesozoic sources to Eocene formations and the Eocene formations to suspended sediment export from the two catchments. For example, the Frysjaodden Formation receives a greater proportion of sediment from the eastern source as compared to the western source. (a) The contribution of Mesozoic sediment sources to Eocene formations is determined by the depositional location (far-shore vs. near-shore), particle size and susceptibility to authigenic phase formation. (b) The contribution of the Paleogene formations to the present-day suspended sediment load is determined by the present-day exposure of the formations in each catchment (Fig. 2) which is determined by the recent erosional history of the catchments.

mation contains authigenic smectite in addition to smectite derived from continental weathering, increasing the relative proportion of smectite in this Formation. In addition to diagenetic changes, adsorption may also occur. Samples containing a greater relative proportion of I/S have a greater cation exchange capacity and are therefore more likely to contain a greater proportion of ions from seawater, increasing the difference between ${ }^{87} \mathrm{Sr} /{ }^{86} \mathrm{Sr}$ and $\varepsilon \mathrm{Nd}$ in the residue and bulk (Dasch, 1969; Ohr et al., 1991). Adsorption of
$\mathrm{Nd}$ from seawater was also implicated in a study by von Blanckenburg and Nägler (2001) where leachates of marine sediments had higher $\varepsilon \mathrm{Nd}$ than bulk. In contrast, terrestrial sediments which had no contact with seawater showed the reverse pattern (lower $\varepsilon \mathrm{Nd}$ in leachate compared to bulk). The greater difference between $\varepsilon \mathrm{Nd}$ in bulk and residue in the Fardalen (unglaciated) stream suspended sediments compared to Dryadbreen (glaciated, Fig. 9b) is therefore consis- 
tent with the greater relative proportion of the Frysjaodden Formation to the Fardalen stream suspended sediments.

Assuming the leached phase is comprised of a mixture of authigenic minerals such as apatite and cations readily leached from clay minerals, then the leachate should have a seawater isotopic composition. Radiogenic $\mathrm{Sr}$ in seawater in the past is relatively well constrained given that it has a uniform value across the worlds oceans. Radiogenic neodymium, on the other hand, varies between ocean basins. A study based on fossil fish debris provides some constraints on the $\varepsilon \mathrm{Nd}$ and ${ }^{87} \mathrm{Sr} /{ }^{86} \mathrm{Sr}$ isotopic composition of the Arctic Ocean during the Eocene (Fig. 1, Gleason et al., 2009), with ${ }^{87} \mathrm{Sr} /{ }^{86} \mathrm{Sr}$ varying from 0.7078 to 0.7088 and $\varepsilon \mathrm{Nd}$ varying from -7.5 to -5.5 . If we assume that the location of this study and the area of the future Central Basin were connected, then this end-member would be within error of the eastern end-member and therefore could not be distinguished (Fig. 8). This is the most likely reason why the two trends (residue-bulk-leachate and east-west bulk) appear to fall on a common mixing line (Fig. 9a). Awwiller (1994) concluded that provenance information based on $\mathrm{Nd}-\mathrm{Sr}$ isotopes could be obscured by the partial incorporation of $\mathrm{Sr}$ and $\mathrm{Nd}$ from seawater. Diagenetic alteration has been implicated in shales which give unrealistically old Nd model ages (Arndt and Goldstein, 1987; Awwiller and Mack, 1991; Bock et al., 1994; Cullers et al., 1997; Krogstad et al., 2004). However, whilst the leached phase is isotopically distinct from bulk it cannot account for the isotopic difference observed between the residual phase isotopic compositions (Fig. 9a). Further, although the potential for diagenetic processes to modify bulk $\varepsilon \mathrm{Nd}$ and ${ }^{87} \mathrm{Sr} /{ }^{86} \mathrm{Sr}$ values cannot be ruled out, it is a subordinate effect to the primary trend of mixing between distinct lithological end-members (Fig. 8).

\subsection{Implications for $\mathrm{Nd}$ as a sediment source tracer}

The stream suspended sediments observed in this study have highly heterogeneous $\mathrm{Nd}$ isotopic compositions with a difference between the two catchments of up to $6.8 \mathrm{ep}$ silon units. Additionally, seasonal variation is observed in the unglaciated Fardalen catchment ( $1.6 \pm 0.4$ epsilon units), but is not resolved in the glaciated Dryadbreen catchment $(0.6 \pm 0.5$ epsilon units). A similar magnitude of seasonal variation in $\varepsilon \mathrm{Nd}$ has previously been reported in the suspended sediments of much larger rivers. A 1.3 epsilon unit seasonal variation has been reported in suspended sediments from the Madeira River (Amazon, Viers et al., 2008) and a 2 epsilon unit range was observed in suspended sediments from two tributaries of the Ganges (Kosi and Narayani, Garçon et al., 2013). The seasonal variation in both of these studies was attributed to the seasonal variation in hydrology which affects how efficient the mixing of tributaries draining different geological units is. The role of hydrology and geology was recently demonstrated at a Canadian glacier where seasonal variations in $\varepsilon \mathrm{Nd}$ in a geologically heteroge- neous catchment were attributed to the changes in subglacial hydrology (distributed to channelised) which altered where erosion occurred (Clinger et al., 2016). In contrast, glacial catchments with more homogenous lithology have little seasonal variation in $\varepsilon \mathrm{Nd}$ (Clinger et al., 2016; Rickli et al., 2017). From this small dataset (this study, Viers et al., 2008; Garçon et al., 2013; Clinger et al., 2016) it would appear that seasonal variations of $\varepsilon \mathrm{Nd}$ in suspended sediments are present where rivers drain mixed geology and have a pronounced seasonality to their hydrological cycle.

For the purposes of using $\mathrm{Nd}$ in ocean sediment cores as a tracer for past sediment sources it is assumed that the $\mathrm{Nd}$ isotopic composition of sediments is constant for broad geographic regions (e.g. Jeandel et al., 2007), and this will not be affected by seasonal variations. However, seasonal cycles give an insight into weathering and erosion conditions under different hydrological regimes that are an analogue for longer term trends. It is entirely plausible that an intensified or weakened hydrological cycle could change the $\mathrm{Nd}$ isotopic composition of sediment export for a given region (Burton and Vance, 2000). Of particular relevance to the Arctic region is the re-organisation of drainage basins as the ice sheets waxed and waned and the attendant changes in magnitude and location of discharge to the ocean (e.g. Teller, 1990; Wickert, 2016). Therefore, it should not necessarily be assumed that the continental regions have had a constant $\varepsilon \mathrm{Nd}$ export to the oceans over glacial-interglacial timescales. For example, the 5.7 epsilon unit range in $\varepsilon \mathrm{Nd}$ (which is of similar magnitude to difference between catchments observed in this study) in an Arctic sediment core (PS1533, Tütken et al., 2002) over the last $140 \mathrm{ka}$ was attributed to changes in the relative proportion of sediment derived from two isotopically distinct sources (Svalbard and Siberia) over glacialinterglacial cycles. Although the broad end-member identification will unlikely be affected, the calculated proportions of each end-member at different points in time would change if the those end-members were not constant over glacialinterglacial cycles.

\section{Conclusions}

The large variations in ${ }^{87} \mathrm{Sr} /{ }^{86} \mathrm{Sr}$ and $\varepsilon \mathrm{Nd}$ observed in sediments from two small catchments in Svalbard can be explained as a result of two isotopically and geochemically distinct sediment sources mixing during the Mesozoic and subsequently forming the Paleocene-Eocene sedimentary formations which are eroding today (Fig. 10). The two original sources are an eastern sediment source derived from basaltic rocks from Siberia and a western sediment source derived from basement rocks from Greenland. The original geology of the sources controls the initial geochemistry, $\mathrm{Sr}$ and $\mathrm{Nd}$ isotope values and subsequently determines the type of clay minerals formed during weathering, susceptibility to later diagenesis and particle-size transport effects. Thus sedimen- 
tary processes in the past have influenced the $\mathrm{Sr}$ and $\mathrm{Nd}$ isotopic composition of the present formations.

In the modern day, changes in erosion caused by the glaciation of Dryadbreen has led to material from the upper (younger) formation, which contains a higher proportion of material derived from the western source, being moved lower down in the catchment where it is present in the moraines and sandur plain. In contrast, the lower (older) formation, which contains a higher proportion of material derived from the eastern source, is fully exposed in the unglaciated catchment, having not been covered by sediment from the upper formations of the catchment. This leads to a marked difference in the suspended sediment export from the two catchments and suggests that changes in continental erosion during glacial-interglacial cycles could have a pronounced effect on the $\mathrm{Sr}$ and $\mathrm{Nd}$ isotopic composition of sediment ex- ported from sedimentary catchments where those sediments have a complex history of multiple sources and sedimentary cycles. Given that the majority of the main rivers in the circum-Arctic region drain shale, the temporal variation of ${ }^{87} \mathrm{Sr} /{ }^{86} \mathrm{Sr}$ and $\varepsilon \mathrm{Nd}$ exported to the ocean from a given region over glacial-interglacial periods may not have been constant. Further changes on the continents occurring during glacial-interglacial cycles (hydrology, basin configuration) should also be considered as factors affecting $\varepsilon \mathrm{Nd}$ variation in ocean sediments.

Data availability. All data used in this article is contained in the included tables apart from XRD data files. For data related queries, please contact the corresponding author. 


\section{Appendix A}

Table A1. Comparison of element concentrations collected by XRF (only available for four samples) and ICP-OES. Data from ICP-OES is used in the paper.

\begin{tabular}{|c|c|c|c|c|c|c|c|c|c|c|c|c|c|c|c|c|c|}
\hline $\begin{array}{l}\text { Name and } \\
\text { description }\end{array}$ & $\begin{array}{l}\mathrm{SiO}_{2} \\
\text { wt \% }\end{array}$ & $\begin{array}{r}\mathrm{Al}_{2} \mathrm{O}_{3} \\
\text { wt \% }\end{array}$ & $\begin{array}{r}\mathrm{Fe}_{2} \mathrm{O}_{3} \\
\text { wt \% }\end{array}$ & $\begin{array}{l}\mathrm{TiO}_{2} \\
\text { wt } \%\end{array}$ & $\begin{array}{l}\mathrm{MgO} \\
\text { wt } \%\end{array}$ & $\begin{array}{l}\mathrm{CaO} \\
\text { wt } \%\end{array}$ & $\begin{array}{r}\mathrm{Na}_{2} \mathrm{O} \\
\text { wt } \%\end{array}$ & $\begin{array}{l}\mathrm{K}_{2} \mathrm{O} \\
\text { wt \% }\end{array}$ & $\begin{array}{l}\mathrm{P}_{2} \mathrm{O}_{5} \\
\text { wt \% }\end{array}$ & $\begin{array}{r}\text { LOI } \\
\text { wt } \%\end{array}$ & $\begin{array}{l}\text { Sum } \\
\text { wt } \%\end{array}$ & $\begin{array}{r}\mathrm{Mn} \\
\mathrm{mg} \mathrm{kg}^{-1}\end{array}$ & $\begin{array}{r}\mathrm{Ba} \\
\mathrm{mg} \mathrm{kg}^{-1}\end{array}$ & $\mathrm{mg} \mathrm{kg}^{-1}$ & $\begin{array}{r}\mathrm{Rb} \\
\mathrm{mg} \mathrm{kg}^{-1}\end{array}$ & $\begin{array}{r}\mathrm{Nd} \\
\mathrm{mg} \mathrm{kg}^{-1}\end{array}$ & $\begin{array}{r}\mathrm{Sm} \\
\mathrm{mg} \mathrm{kg}^{-1}\end{array}$ \\
\hline \multicolumn{18}{|c|}{ Data collected by XRF } \\
\hline R01 & 63.2 & 16.3 & 7.1 & 0.8 & 1.4 & 0.3 & 1.0 & 2.6 & 0.3 & 7.5 & 100.5 & 488 & 403 & 97.4 & 102 & 35 & $<10$ \\
\hline R02 & 65.4 & 13.0 & 7.9 & 0.6 & 1.5 & 0.6 & 0.7 & 2.2 & 0.3 & 7.2 & 99.4 & 1038 & 357 & 81.9 & 88.8 & 27 & $<10$ \\
\hline R03 & 70.9 & 8.9 & 3.2 & 0.6 & 0.9 & 6.2 & 1.1 & 1.6 & 0.1 & 7.0 & 100.5 & 472 & 356 & 142 & 55.1 & 23 & $<10$ \\
\hline R04 & 57.1 & 19.1 & 3.5 & 0.9 & 1.3 & 0.2 & 0.6 & 3.6 & 0.1 & 12.9 & 99.3 & 178 & 511 & 116 & 150 & 42 & $<10$ \\
\hline \multicolumn{18}{|c|}{ Data collected by ICP-OES* } \\
\hline R01 & 63.2 & 15.7 & 7.1 & 0.8 & 1.4 & 0.4 & 1.1 & 2.4 & 0.2 & 7.9 & 100.0 & 497 & 438 & 98 & 103 & 32 & 6 \\
\hline R02 & 64.7 & 12.6 & 8.0 & 0.6 & 1.4 & 0.6 & 0.8 & 2.1 & 0.3 & 8.9 & 100.0 & 1056 & 371 & 83 & 89 & 26 & 5 \\
\hline R03 & 70.0 & 8.6 & 3.3 & 0.6 & 0.9 & 6.1 & 1.1 & 1.5 & 0.1 & 7.7 & 100.0 & 480 & 366 & 139 & 54 & 25 & 5 \\
\hline R04 & 58.3 & 18.5 & 3.5 & 0.9 & 1.3 & 0.2 & 0.7 & 3.2 & 0.1 & 13.3 & 100.0 & 190 & 542 & 107 & 147 & 39 & 7 \\
\hline
\end{tabular}

* $\mathrm{SiO}_{2}$ concentrations calculated by assuming $100 \%$ recovery.

Table A2. Rare earth element concentrations in $\mathrm{mg} \mathrm{kg}^{-1, \mathrm{a}, \mathrm{b}}$.

\begin{tabular}{|c|c|c|c|c|c|c|c|c|c|c|c|c|c|c|}
\hline Sample ${ }^{b}$ & $\mathrm{La}$ & $\mathrm{Ce}$ & $\operatorname{Pr}$ & $\mathrm{Nd}$ & $\mathrm{Sm}$ & $\mathrm{Eu}$ & Gd & $\mathrm{Tb}$ & Dy & Ho & Er & $\mathrm{Tm}$ & $\mathrm{Yb}$ & $\mathrm{Lu}$ \\
\hline \multicolumn{15}{|c|}{ Sedimentary rock samples } \\
\hline R01 & 35.7 & 71.2 & 8.4 & 32.4 & 6.0 & 1.2 & 4.5 & 0.7 & 4.0 & 0.7 & 2.0 & 0.3 & 1.9 & 0.3 \\
\hline G & 35.7 & 70.4 & 8.3 & 32.3 & 6.0 & 1.3 & 4.6 & 0.7 & 4.2 & 0.8 & 2.3 & 0.3 & 2.2 & 0.3 \\
\hline R04 & 49.1 & 95.4 & 10.7 & 39.3 & 6.6 & 1.3 & 4.0 & 0.7 & 3.5 & 0.7 & 1.9 & 0.3 & 1.8 & 0.2 \\
\hline R02 & 28.5 & 55.5 & 6.6 & 25.7 & 4.8 & 1.1 & 3.8 & 0.6 & 3.2 & 0.6 & 1.7 & 0.2 & 1.5 & 0.2 \\
\hline R03 & 30.5 & 60.3 & 6.8 & 25.4 & 4.5 & 0.9 & 3.1 & 0.4 & 2.2 & 0.4 & 1.0 & 0.1 & 0.9 & 0.1 \\
\hline \multicolumn{15}{|l|}{ Sediment sample } \\
\hline $\mathrm{D}$ & 43.9 & 88.5 & 9.9 & 36.5 & 6.5 & 1.2 & 4.3 & 0.6 & 3.3 & 0.6 & 1.6 & 0.2 & 1.4 & 0.2 \\
\hline \multicolumn{15}{|c|}{ Stream sediment samples } \\
\hline $\mathrm{L}$ & 37.1 & 72.8 & 8.3 & 31.6 & 5.8 & 1.2 & 4.4 & 0.7 & 4.0 & 0.8 & 2.2 & 0.3 & 2.0 & 0.3 \\
\hline $\mathrm{O}$ & 37.9 & 76.3 & 8.7 & 33.4 & 5.9 & 1.1 & 4.2 & 0.6 & 3.1 & 0.5 & 1.4 & 0.2 & 1.3 & 0.2 \\
\hline \multicolumn{15}{|c|}{$<2 \mu \mathrm{m}$ fraction of bulk rock and sediment samples } \\
\hline R01-clay & 37.0 & 72.7 & 9.4 & 38.1 & 8.0 & 1.8 & 7.1 & 1.0 & 5.8 & 1.0 & 2.8 & 0.4 & 2.5 & 0.3 \\
\hline R04-clay & 38.9 & 78.0 & 8.6 & 31.9 & 5.8 & 1.0 & 3.7 & 0.6 & 3.5 & 0.7 & 2.0 & 0.3 & 2.0 & 0.3 \\
\hline G-clay & 32.4 & 64.3 & 8.0 & 32.6 & 6.5 & 1.5 & 5.7 & 0.9 & 4.8 & 0.9 & 2.4 & 0.3 & 2.2 & 0.3 \\
\hline D-clay & 31.5 & 64.0 & 7.0 & 25.9 & 4.8 & 1.0 & 3.8 & 0.6 & 3.4 & 0.7 & 1.8 & 0.3 & 1.7 & 0.2 \\
\hline L-clay & 30.5 & 60.4 & 7.1 & 29.0 & 6.0 & 1.4 & 5.4 & 0.9 & 4.9 & 1.0 & 2.7 & 0.4 & 2.5 & 0.4 \\
\hline \multicolumn{15}{|c|}{ Stream suspended sediments (bulk) } \\
\hline 20120801SG & 41.8 & 82.8 & 9.4 & 34.4 & 6.2 & 1.2 & 4.2 & 0.6 & 3.3 & 0.6 & 1.6 & 0.2 & 1.5 & 0.2 \\
\hline 20120617D & 40.3 & 79.3 & 9.1 & 34.1 & 6.2 & 1.2 & 4.3 & 0.6 & 3.5 & 0.6 & 1.6 & 0.2 & 1.5 & 0.2 \\
\hline $20120618 \mathrm{~F}$ & 40.9 & 84.5 & 10.0 & 40.3 & 8.2 & 1.8 & 7.1 & 1.0 & 5.4 & 1.0 & 2.5 & 0.3 & 2.0 & 0.3 \\
\hline $20120726 \mathrm{~F}$ & 44.3 & 89.6 & 10.4 & 41.8 & 8.6 & 1.9 & 7.7 & 1.2 & 6.3 & 1.1 & 2.9 & 0.4 & 2.4 & 0.3 \\
\hline 20120729D & 44.6 & 88.9 & 9.9 & 37.3 & 6.6 & 1.3 & 4.7 & 0.7 & 3.7 & 0.7 & 1.8 & 0.3 & 1.7 & 0.3 \\
\hline \multicolumn{15}{|c|}{ Stream suspended sediments (acid-treated) } \\
\hline $20120617 \mathrm{D}(\mathrm{HCl})$ & 38.1 & 72.8 & 7.9 & 28.6 & 4.5 & 0.7 & 2.3 & 0.4 & 2.2 & 0.4 & 1.3 & 0.2 & 1.3 & 0.2 \\
\hline $20120618 \mathrm{~F}(\mathrm{HCl})$ & 36.8 & 71.0 & 7.8 & 27.8 & 4.2 & 0.9 & 2.5 & 0.4 & 2.7 & 0.5 & 1.5 & 0.2 & 1.7 & 0.2 \\
\hline $20120726 \mathrm{~F}(\mathrm{HCl})$ & 42.2 & 81.2 & 8.8 & 30.7 & 4.7 & 0.9 & 2.7 & 0.5 & 3.0 & 0.6 & 1.7 & 0.3 & 1.8 & 0.2 \\
\hline $20120729 \mathrm{D}(\mathrm{HCl})$ & 42.1 & 80.4 & 8.8 & 31.7 & 4.7 & 0.9 & 2.5 & 0.4 & 2.4 & 0.5 & 1.4 & 0.2 & 1.4 & 0.2 \\
\hline
\end{tabular}


Table A3. Measurements of four USGS standards by ICP-OES compared to certificate values.

\begin{tabular}{|c|c|c|c|c|c|c|c|c|c|c|}
\hline Standard & $\begin{array}{l}\mathrm{SiO}_{2} \\
\mathrm{wt} \%\end{array}$ & $\begin{array}{r}\mathrm{Al}_{2} \mathrm{O}_{3} \\
\text { wt } \%\end{array}$ & $\begin{array}{r}\mathrm{Fe}_{2} \mathrm{O}_{3} \\
\text { wt } \%\end{array}$ & $\begin{array}{l}\mathrm{TiO}_{2} \\
\text { wt \% }\end{array}$ & $\begin{array}{l}\mathrm{MgO} \\
\text { wt \% }\end{array}$ & $\begin{array}{l}\mathrm{CaO} \\
\text { wt } \%\end{array}$ & $\begin{array}{r}\mathrm{Na}_{2} \mathrm{O} \\
\text { wt } \%\end{array}$ & $\begin{array}{l}\mathrm{K}_{2} \mathrm{O} \\
\text { wt \% }\end{array}$ & $\begin{array}{r}\mathrm{P}_{2} \mathrm{O}_{5} \\
\text { wt } \%\end{array}$ & $\begin{array}{r}\text { LOI } \\
\text { wt } \%\end{array}$ \\
\hline \multicolumn{11}{|l|}{ SGR-1b } \\
\hline Mean $(n=8)$ & $30.7^{*}$ & 6.3 & 3.3 & 0.3 & 4.4 & 8.1 & 3.1 & 1.6 & 0.1 & 42.2 \\
\hline $2 \mathrm{SD}$ & & 0.4 & 0.2 & 0.0 & 0.3 & 0.3 & 0.1 & 0.1 & 0.0 & 0.5 \\
\hline Ref. value & 28.2 & 6.5 & 3.0 & 0.3 & 4.4 & 8.4 & 3.0 & 1.7 & 0.3 & \\
\hline \multicolumn{11}{|l|}{ G-2 } \\
\hline Mean $(n=2)$ & $69.0^{*}$ & 14.9 & 3.0 & 0.6 & 0.7 & 2.0 & 4.2 & 4.2 & 0.1 & 1.4 \\
\hline $2 \mathrm{SD}$ & & 0.3 & 0.0 & 0.0 & 0.0 & 0.0 & 0.1 & 0.1 & 0.0 & 0.7 \\
\hline Ref. value & 69.1 & 15.4 & 2.7 & 0.5 & 0.8 & 2.0 & 4.1 & 4.5 & 0.1 & \\
\hline \multicolumn{11}{|l|}{ BCR-2 } \\
\hline Mean $(n=4)$ & $51.5^{*}$ & 13.1 & 16.5 & 2.6 & 3.5 & 7.0 & 3.3 & 1.9 & 0.1 & 0.5 \\
\hline $2 \mathrm{SD}$ & & 0.3 & 1.1 & 0.1 & 0.1 & 0.1 & 0.1 & 0.1 & 0.1 & 0.0 \\
\hline Ref. value & 54.1 & 13.5 & 13.8 & 2.3 & 3.6 & 7.1 & 3.2 & 1.8 & 0.4 & \\
\hline \multicolumn{11}{|l|}{ AGV-2 } \\
\hline Mean $(n=2)$ & $58.5^{*}$ & 16.4 & 7.6 & 1.2 & 1.7 & 5.2 & 4.3 & 2.9 & 0.2 & 2.1 \\
\hline $2 \mathrm{SD}$ & & 0.4 & 0.2 & 0.1 & 0.0 & 0.4 & 0.2 & 0.2 & 0.1 & \\
\hline Ref. value & 59.3 & 16.9 & 6.7 & 1.1 & 1.8 & 5.2 & 4.2 & 2.9 & 0.5 & \\
\hline
\end{tabular}

* $\mathrm{SiO}_{2}$ concentrations calculated assuming $100 \%$ recovery. For a comparison of XRF and ICP-OES concentrations see Table A1.

Table A4. Measurements of four USGS standards by ICP-MS compared to literature values*. Concentrations are in $\mathrm{mg} \mathrm{kg}^{-1}$.

\begin{tabular}{|c|c|c|c|c|c|c|c|c|c|c|c|c|c|c|c|c|c|c|}
\hline Standard & $\mathrm{Mn}$ & $\mathrm{Rb}$ & $\mathrm{Sr}$ & $\mathrm{Ba}$ & $\mathrm{La}$ & $\mathrm{Ce}$ & $\operatorname{Pr}$ & $\mathrm{Nd}$ & $\mathrm{Sm}$ & $\mathrm{Eu}$ & Gd & $\mathrm{Tb}$ & Dy & Ho & $\mathrm{Er}$ & $\mathrm{Tm}$ & $\mathrm{Yb}$ & $\mathrm{Lu}$ \\
\hline \multicolumn{19}{|l|}{ Sco-1 } \\
\hline Mean $(n=12)$ & 431 & 115 & 160 & 627 & 30.2 & 59 & 7.0 & 27 & 5.2 & 1.07 & 4.2 & 0.6 & 3.5 & 0.69 & 1.9 & 0.28 & 1.79 & 0.26 \\
\hline $2 \mathrm{SD}$ & 69 & 19 & 20 & 72 & 4.4 & 7 & 0.5 & 1 & 0.2 & 0.08 & 0.2 & 0.0 & 0.2 & 0.06 & 0.1 & 0.03 & 0.14 & 0.03 \\
\hline Govindaraju (1994) & 410 & 112 & 174 & 570 & 29.5 & 62 & 6.6 & 26 & 5.3 & 1.19 & 4.6 & 0.7 & 4.2 & 0.97 & 2.5 & 0.42 & 2.27 & 0.34 \\
\hline \multicolumn{19}{|l|}{ BIR-1 } \\
\hline Mean $(n=6)$ & 1419 & 0.22 & 105 & 7 & 0.69 & 1.89 & 0.36 & 2.4 & 1.1 & 0.54 & 1.98 & 0.37 & 2.6 & 0.58 & 1.7 & 0.26 & 1.72 & 0.26 \\
\hline $2 \mathrm{SD}$ & 155 & 0.09 & 10 & 1 & 0.09 & 0.19 & 0.02 & 0.0 & 0.0 & 0.04 & 0.05 & 0.01 & 0.2 & 0.03 & 0.1 & 0.01 & 0.09 & 0.02 \\
\hline Govindaraju (1994) & 1324 & 0.25 & 108 & 7 & 0.62 & 1.95 & 0.38 & 2.5 & 1.1 & 0.54 & 1.85 & 0.36 & 2.5 & 0.57 & 1.7 & 0.26 & 1.65 & 0.26 \\
\hline \multicolumn{19}{|l|}{ BHVO-2 } \\
\hline Mean $(n=7)$ & 1358 & 9.59 & 372 & 133 & 15.1 & 37.0 & 5.16 & 24.1 & 6.05 & 2.09 & 6.41 & 0.95 & 5.34 & 0.99 & 2.56 & 0.34 & 2.05 & 0.28 \\
\hline $2 \mathrm{SD}$ & 89 & 0.98 & 35 & 14 & 1.7 & 4.0 & 0.39 & 1.2 & 0.26 & 0.06 & 0.22 & 0.03 & 0.24 & 0.04 & 0.09 & 0.01 & 0.09 & 0.01 \\
\hline Raczek et al. (2001) & 1317 & 9.08 & 396 & 131 & 15.2 & 37.5 & 5.29 & 24.5 & 6.07 & 2.07 & 6.24 & 0.94 & 5.32 & 0.97 & 2.54 & 0.34 & 2.00 & 0.27 \\
\hline \multicolumn{19}{|l|}{ BCR-2 } \\
\hline Mean $(n=9)$ & 1523 & 47.3 & 312 & 657 & 23.7 & 50.2 & 6.39 & 27.4 & 6.34 & 1.88 & 6.62 & 1.04 & 6.29 & 1.27 & 3.61 & 0.53 & 3.37 & 0.50 \\
\hline $2 \mathrm{SD}$ & 142 & 5.8 & 31 & 44 & 2.3 & 4.1 & 0.38 & 0.8 & 0.14 & 0.05 & 0.08 & 0.02 & 0.22 & 0.04 & 0.15 & 0.02 & 0.14 & 0.02 \\
\hline Raczek et al. (2001) & 1471 & 46.9 & 340 & 677 & 24.9 & 52.9 & 6.57 & 28.7 & 6.57 & 1.96 & 6.75 & 1.07 & 6.42 & 1.30 & 3.66 & 0.56 & 3.38 & 0.52 \\
\hline \multicolumn{19}{|l|}{ AGV-2 } \\
\hline Mean $(n=6)$ & 785 & 70.3 & 616 & 1141 & 37.7 & 68.3 & 7.94 & 30.2 & 5.48 & 1.43 & 4.29 & 0.64 & 3.49 & 0.67 & 1.85 & 0.27 & 1.68 & 0.25 \\
\hline $2 \mathrm{SD}$ & 75 & 8.2 & 45 & 121 & 4.1 & 6.8 & 0.54 & 1.4 & 0.22 & 0.05 & 0.23 & 0.01 & 0.15 & 0.04 & 0.10 & 0.01 & 0.08 & 0.01 \\
\hline Raczek et al. (2001) & 774 & 66.3 & 661 & 1130 & 37.9 & 68.6 & 7.68 & 30.5 & 5.49 & 1.53 & 4.52 & 0.64 & 3.47 & 0.65 & 1.81 & 0.26 & 1.62 & 0.25 \\
\hline
\end{tabular}

* The hotplate digestion method used does not digest zircons and this accounts for the low recovery of the HREE in the sedimentary standard SCo-1. 
Competing interests. The authors declare that they have no conflict of interest.

Acknowledgements. This project was funded by a Swiss National Science Foundation fellowship for prospective researchers (PBEZP2-137335), a Marie Curie Intra-European Fellowship (PIEF-GA-2012-331501) and NERC Standard Grant NE/M001865/1. Fieldwork was supported by an Arctic Field Grant (219165/E10, The Research Council of Norway). We wish to thank the fieldwork team and everyone who made the fieldwork possible, Angus Calder (University of St. Andrews) for help with XRD analysis, Chris Jeans (University of Cambridge) for help with the semi-quantitative analysis of clay minerals by XRD and Tim Heaton (British Geological Survey) for performing the stream suspended sediment leaches. We thank the two reviewers and the $\mathrm{AE}$ for their comments which have helped to considerably improve this article.

Edited by: Valier Galy

Reviewed by: two anonymous referees

\section{References}

Arndt, N. T. and Goldstein, S. L.: Use and abuse of crust-formation ages, Geology, 15, 893-895, 1987.

Aubert, D., Stille, P., and Probst, A.: REE fractionation during granite weathering and removal by waters and suspended loads: $\mathrm{Sr}$ and $\mathrm{Nd}$ isotopic evidence, Geochim. Cosmochim. Ac., 65, 387406, 2001

Awwiller, D. N.: Geochronology and mass transfer in Gulf Coast mudrocks (south-central Texas, U.S.A.): Rb-Sr, Sm-Nd and REE systematics, Chem. Geol., 116, 61-84, 1994.

Awwiller, D. N. and Mack, L. E.: Diagenetic modification of Sm-Nd model ages in Tertiary sandstones and shales, Texas Gulf Coast, Geology, 19, 311-314, 1991.

Babechuk, M. G., Widdowson, M., Murphy, M., and Kamber, B. S.: A combined Y/Ho, high field strength element (HFSE) and $\mathrm{Nd}$ isotope perspective on basalt weathering, Deccan Traps, India, Chem. Geol., 369, 25-41, 2015.

Bayon, G., Toucanne, S., Skonieczny, C., André, L., Bermell, S., Cheron, S., Dennielou, B., Etoubleau, J., Freslon, N., Gauchery, T., Germain, Y., Jorry, S. J., Ménot, G., Monin, L., Ponzevera, E., Rouget, M.-L., Tachikawa, K., and Barrat, J. A.: Rare earth elements and neodymium isotopes in world river sediments revisited, Geochim. Cosmochim. Ac., 170, 17-38, https://doi.org/10.1016/j.gca.2015.08.001, 2015.

Bernstein, S., Kelemen, P. B., Tegner, C., Kurz, M. D., Blusztajn, J., and Brooks, C. K.: Post-breakup basaltic magmatism along the East Greenland Tertiary rifted margin, Earth Planet. Sc. Lett., 160, 845-862, 1998.

Bock, B., McLennan, S. M., and Hanson, G. N.: Rare earth element redistribution and its effects on the neodymium isotope system in the Austin Glen Member of the Normanskill Formation, New York, USA, Geochim. Cosmochim. Ac., 58, 5245-5253, 1994.

Bue, E. P. and Andresen, A.: Constraining depositional models in the Barents Sea region using detrital zircon $\mathrm{U}-\mathrm{Pb}$ data from Mesozoic sediments in Svalbard, in: Sediment provenance stud- ies in hydrocarbon exploration and production, edited by: Scott, R. A., Smyth, H. R., Morton, A. C., and Richardson, N., no. 386 in Special Publications, Geological Society, Bath, UK, 261-279, 2014.

Bullen, T., White, A., Blum, A., Harden, J., and Schulz, M.: Chemical weathering of a soil chronosequence on granitoid alluvium: II. Mineralogic and isotopic constraints on the behavior of strontium, Geochim. Cosmochim. Ac., 61, 291-306, 1997.

Burton, K. W. and Vance, D.: Glacial-interglacial variations in the neodymium isotope composition of seawater in the Bay of Bengal recorded by planktonic foraminifera, Earth Planet. Sc. Lett., 176, 425-441, 2000.

Byrne, R. H. and Kim, K.-H.: Rare earth element scavenging in seawater, Geochim. Cosmochim. Ac., 54, 2645-2656, 1990.

Byrne, R. H. and Sholkovitz, E. R.: Marine chemistry and geochemistry of the lanthanides, in: Handbook on the Physics and Chemistry of Rare Earths, edited by: Gschneidner Jr., K. A. and Eyring, L., vol. 23, chap. 158, 497-593, Elsevier Science B. V., Oxford, UK, 1996.

Cameron, E. M. and Hattori, K.: Strontium and neodymium isotope ratios in the Fraser River, British Columbia: a riverine transect across the Cordilleran orogen, Chem. Geol., 137, 243-253, 1997.

Charles, A. J., Condon, D. J., Harding, I. C., Pälike, H., Marshall, J. E. A., Cui, Y., Kump, L., and Croudace, I. W.: Constraints on the numerical age of the PaleoceneEocene boundary, Geochem. Geophy. Geosy., 12, Q0AA17, https://doi.org/10.1029/2010GC003426, 2011.

Chester, R. and Hughes, M. J.: A chemical technique for the separation of ferro-manganese minerals, carbonate minerals and adsorbed trace elements from pelagic sediments, Chem. Geol., 2, 249-262, 1967.

Clinger, A. E., Aciego, S. M., Stevenson, E. I., Arendt, C. A., and Robbins, M. J.: Implications for post-comminution processes in subglacial suspended sediment using coupled radiogenic strontium and neodymium isotopes, Geomorphology, 259, 134-144, https://doi.org/10.1016/j.geomorph.2016.02.006, 2016.

Collerson, K. D., McCulloch, M. T., and Nutman, A. P.: Sr and Nd isotope systematics of polymetamorphic Archean gneisses from southern West Greenland and northern Labrador, Can J. Earth Sci., 26, 446-466, 1989.

Cui, Y., Kump, L. R., Ridgwell, A. J., Charles, A. J., Junium, C. K., Diefendorf, A. F., Freeman, K. H., Urban, N. M., and Harding, I. C.: Slow release of fossil carbon during the PalaeoceneEocene Thermal Maximum, Nat. Geosci., 4, 481-485, 2011.

Cullers, R. L., Bock, B., and Guidotti, C.: Elemental distributions and neodymium isotopic compositions of Silurian metasediments, western Maine, USA: Redistribution of the rare earth elements, Geochim. Cosmochim. Ac., 61, 1847-1861, 1997.

Curtin, D. and Smillie, G. W.: Composition and origin of smectite in soils derived from basalt in Northern Ireland, Clay Clay Miner., 29, 277-284, 1981.

Dasch, E. J.: Strontium isotopes in weathering profiles, deep-sea sediments, and sedimentary rocks, Geochim. Cosmochim. Ac., 33, 1521-1552, 1969.

Dypvik, H., Riber, L., Burca, F., Rüther, D., Jargvoll, D., Nagy, J., and Jochmann, M.: The Paleocene-Eocene thermal maximum (PETM) in Svalbard - clay mineral and geochemical signals, Palaeogeogr. Palaeocl., 302, 156-169, 2011. 
Eisenhauer, A., Meyer, H., Rachold, V., Tütken, T., Wiegand, B., Hansen, B. T., Spielhagen, R. F., Lindemann, F., and Kassens, H.: Grain size separation and sediment mixing in Arctic Ocean sediments: evidence from the strontium isotope systematic, Chem. Geol., 158, 173-188, 1999.

Elling, F. J., Spiegel, C., Estrada, S., Davis, D. W., Reinhardt, L., Henjes-Kunst, F., Allroggen, N., Dohrmann, R., Piepjohn, K., and Lisker, F.: Origin of bentonites and detrital zircons of the Paleocene Basilika Formation, Svalbard, Front. Earth Sci., 4, 73, https://doi.org/10.3389/feart.2016.00073, 2016.

Essington, M. E.: Soil and Water Chemistry: An Integrative Approach, CRC Press, Boca Raton, Florida, USA, 2004.

Fagel, N., Not, C., Gueibe, J., Mattielli, N., and Bazhenova, E.: Late Quaternary evolution of sediment provenances in the Central Arctic Ocean: mineral assemblage, trace element composition and $\mathrm{Nd}$ and $\mathrm{Pb}$ isotope fingerprints of detrital fraction from the Northern Mendeleev Ridge, Quaternary Sci. Rev., 92, 140154, 2014.

Friend, C. R. L., Nutman, A. P., Baadsgaard, H., and Duke, M. J. M.: The whole rock Sm-Nd "age" for the 2825 Ma Ikkattoq gneisses (Greenland) is $800 \mathrm{Ma}$ too young: Insights into Archaean TTG petrogenesis, Chem. Geol., 261, 62-76, 2009.

Garçon, M. and Chauvel, C.: Where is basalt in river sediments, and why does it matter?, Earth Planet. Sc. Lett., 407, 61-69, 2014.

Garçon, M., Chauvel, C., France-Lanord, C., Huyghe, P., and Lavé, J.: Continental sedimentary processes decouple $\mathrm{Nd}$ and $\mathrm{Hf}$ isotopes, Geochim. Cosmochim. Ac., 121, 177-195, 2013.

Gleason, J. D., Thomas, D. J., Moore Jr., T. C., Blum, J. D., Owen, R. M., and Haley, B. A.: Early to middle Eocene history of the Arctic Ocean from Nd-Sr isotopes in fossil fish debris, Lomonosov Ridge, Paleoceanography, 24, PA2215, https://doi.org/10.1029/2008PA001685, 2009.

Goldstein, S. L. and Jacobsen, S. B.: The Nd and Sr isotopic systematics of river-water dissolved material: Implications for the sources of Nd and $\mathrm{Sr}$ in seawater, Chem. Geol., 66, 245-272, 1987.

Goldstein, S. L. and Jacobsen, S. B.: Nd and Sr isotopic systematics of river water suspended material: Implications for crustal evolution, Earth Planet. Sc. Lett., 87, 249-265, 1988.

Govindaraju, K.: 1994 compilation of working values and sample descriptions for 383 geostandards, Geostandard. Newslett., 18, 1-158, 1994.

Griffin, G. M.: Interpretation of X-ray diffraction data, in: Procedures in sedimentary petrology, edited by: Carver, R. E., WileyInterscience, New York, USA, 541-569, 1971.

Griffin, J. J., Windom, H., and Goldberg, E. D.: The distribution of clay minerals in the World Ocean, Deep-Sea Res., 15, 433-459, 1968.

Haley, B. A., Klinkhammer, G. P., and McManus, J.: Rare earth elements in pore waters of marine sediments, Geochim. Cosmochim. Ac., 68, 1265-1279, 2004.

Helland-Hansen, W.: Sedimentation in Paleogene Foreland Basin, Spitsbergen, AAPG Bull., 74, 260-272, 1990.

Henriksen, N.: Conclusion of the 1:500000 mapping project in the Caledonian fold belt in North-East Greenland, in: Review of Greenland activities 1998, edited by: Higgins, A. K. and Watt, W. S., vol. 183, Geology of Greenland Survey Bulletin, 10-22, GEUS, Copenhagen, Denmark, 1999.
Herron, M. M.: Geochemical classification of terrigenous sands and shales from core or log data, J. Sediment. Petrol., 58, 820-829, 1988.

Hillaire-Marcel, C., Maccali, J., Not, C., and Poirier, A.: Geochemical and isotopic tracers of Arctic sea ice sources and export with special attention to the Younger Dryas interval, Quaternary Sci Rev., 79, 184-190, 2013.

Hindshaw, R. S.: Chemical weathering and calcium isotope fractionation in a glaciated catchment, PhD thesis, ETH Zurich, Zurich, Switzerland, 2011.

Hindshaw, R. S., Heaton, T. H. E., Boyd, E. S., Lindsay, M. R., and Tipper, E. T.: Influence of glaciation on mechanisms of mineral weathering in two high Arctic catchments, Chem. Geol., 420, 37-50, https://doi.org/10.1016/j.chemgeo.2015.11.004, 2016.

Humlum, O., Instanes, A., and Sollid, J. L.: Permafrost in Svalbard: a review of research history, climatic background and engineering challenges, Polar Res., 22, 191-215, https://doi.org/10.3402/polar.v22i2.6455, 2003.

Jacobsen, S. B.: Isotopic constraints on crustal growth and recycling, Earth Planet. Sc. Lett., 90, 315-329, 1988.

Jacobsen, S. B. and Wasserburg, G. J.: Sm-Nd isotopic evolution of chondrites, Earth Planet. Sc. Lett., 50, 139-155, 1980.

Jakobsson, M., Backman, J., Rudels, B., Nycander, J., Frank, M., Mayer, L., Jokat, W., Sangiorgi, F., O’Regan, M., Brinkhuis, H., King, J., and Moran, K.: The early Miocene onset of a ventilated circulation regime in the Arctic Ocean, Nature, 447, 986-990, 2007.

Jeandel, C., Arsouze, T., Lacan, F., Téchiné, P., and Dutay, J.-C.: Isotopic $\mathrm{Nd}$ compositions and concentrations of the lithogenic inputs into the ocean: a compilation, with an emphasis on the margins, Chem. Geol., 239, 156-164, 2007.

Johannesson, K. H. and Zhou, X.: Origin of middle rare earth element enrichments in acid waters of a Canadian High Arctic Lake, Geochim. Cosmochim. Ac., 63, 153-165, 1999.

Johansson, A. and Gee, D. G.: The late Palaeoproterozoic Eskolabreen granitoids of southern Ny Friesland, Svalbard Caledonides - geochemistry, age, and origin, GFF, 121, 113-126, 1999.

Johansson, Å., Gee, D. G., Björklund, L., and Witt-Nilsson, P.: Isotope studies of granitoids from the Bangenhuk Formation, Ny Friesland Caledonides, Svalbard, Geol. Mag., 132, 303-320, 1995.

Jones, M. T., Eliassen, G. T., Shephard, G. E., Svensen, H. H., Jochmann, M., Friis, B., Augland, L. E., Jerram, D. A., and Planke, S.: Provenance of bentonite layers in the Paleocene strata of the Central Basin, Svalbard: implications for magmatism and rifting events around the onset of the North Atlantic Igneous Province, J. Volcanol. Geoth. Res., 327, 571-584, 2016.

Kalsbeek, F. and Frei, R.: The Mesoproterozoic Midsommers $\varnothing$ dolerites and associated high-silica intrusions, North Greenland: crustal melting, contamination and hydrothermal alteration, Contrib. Mineral. Petr., 152, 89-110, 2006.

Knies, J. and Gaina, C.: Middle Miocene ice sheet expansion in the Arctic: Views from the Barents Sea, Geochem. Geophy. Geosy., 9, Q02015, https://doi.org/10.1029/2007GC001824, 2008.

Knies, J., Mattingsdal, R., Fabian, K., Grøsfjeld, K., Baranwal, S., Husum, K., De Schepper, S., Vogt, C., Andersen, N., Matthiessen, J., Andreassen, K., Jokat, W., Nam, S.-I., and Gaina, C.: Effect of early Pliocene uplift on late Pliocene cool- 
ing in the Arctic-Atlantic gateway, Earth Planet. Sc. Lett., 387, 132-144, 2014.

Krogstad, E. J., Fedo, C. M., and Eriksson, K. A.: Provenance ages and alteration histories of shales from the Middle Archean Buhwa greenstone belt, Zimbabwe: $\mathrm{Nd}$ and $\mathrm{Pb}$ isotopic evidence, Geochim. Cosmochim. Ac., 68, 319-332, 2004.

Lightfoot, P. C., Hawkesworth, C. J., Hergt, J., Naldrett, A. J., Gorbachev, N. S., Fedorenko, V. A., and Doherty, W.: Remobilisation of the continental lithosphere by a mantle plume: major-, trace-element, and $\mathrm{Sr}-, \mathrm{Nd}-$, and $\mathrm{Pb}$-isotope evidence from picritic and tholeiitic lavas of the Noril'sk District, Siberian Trap, Russia, Contrib. Mineral. Petr., 114, 171-188, 1993.

Lupker, M., France-Lanord, C., Galy, A., Lavé, J., and Kudrass, H.: Increasing chemical weathering in the Himalayan system since the Last Glacial Maximum, Earth Planet. Sc. Lett., 365, 243$252,2013$.

Ma, J., Wei, G., Xu, Y., and Long, W.: Variations of Sr-Nd-Hf isotopic systematics in basalt during intensive weathering, Chem. Geol., 269, 376-385, 2010.

Maccali, J., Hillaire-Marcel, C., Carignan, J., and Reisberg, L. C.: Geochemical signatures of sediments documenting Arctic seaice and water mass export through Fram Strait since the Last Glacial Maximum, Quaternary Sci. Rev., 64, 136-151, https://doi.org/10.1016/j.quascirev.2012.10.029, 2013.

Major, H., Haremo, P., Dallmann, W. K., and Andresen, A.: Geological map of Svalbard 1:100000, sheet C9G Adventdalen, Temakart nr. 31, Norsk Polarinstitutt, Troms $\varnothing$, Norway, 2000.

McCulloch, M. T. and Wasserburg, G. J.: Sm-Nd and Rb-Sr chronology of continental crust formation, Science, 200, 10031011, 1978.

McLennan, S. M., McCulloch, M. T., Taylor, S. R., and Maynard, J. B.: Effects of sedimentary sorting on neodymium isotopes in deep-sea turbidites, Nature, 337, 547-549, 1989.

Meinhardt, A.-K., Pahnke, K., Böning, B., Schnetger, B., and Brumsack, H.-J.: Climate change and response in bottom water circulation and sediment provenance in the Central Arctic Ocean since the Last Glacial, Chem. Geol., 427, 98-108, 2016.

Millero, F. J.: Stability constants for the formation of rare earth inorganic complexes as a function of ionic strength, Geochim. Cosmochim. Ac., 56, 3123-3132, 1992.

Mokadem, F., Parkinson, I. J., Hathorne, E. C., Anand, P., Allen, J. T., and Burton, K. W.: High-precision radiogenic strontium isotope measurements of the modern and glacial ocean: Limits on glacial-interglacial variations in continental weathering, Earth Planet. Sc. Lett., 415, 111-120, https://doi.org/10.1016/j.eps1.2015.01.036, 2015.

Moore, D. M. and Reynolds Jr., R. C.: X-ray diffraction and the identification and analysis of clay minerals, Oxford University Press, New York, USA, 1997.

Müller, R. D. and Spielhagen, R. F.: Evolution of the Central Tertiary Basin of Spitsbergen: towards a synthesis of sediment and plate tectonic history, Palaeogeogr. Palaeocl., 80, 153-172, 1990.

Nordli, Ø., Przybylak, R., Ogilvie, A. E. J., and Isaksen, K.: Longterm temperature trends and variability on Spitsbergen: the extended Svalbard Airport temperature series, 1898-2012, Polar Res., 33, 21349, https://doi.org/10.3402/polar.v33.21349, 2012.

Nürnberg, D., Wollenburg, I., Dethleff, D., Eicken, H., Kassens, H., Letzig, T., Reimnitz, E., and Thiede, J.: Sediments in Arc- tic sea ice: Implications for entrainment, transport and release, Mar. Geol., 119, 185-214, 1994.

Öhlander, B., Ingri, J., Land, M., and Schöberg, H.: Change of Sm$\mathrm{Nd}$ isotope composition during weathering of till, Geochim. Cosmochim. Ac., 64, 813-820, 2000.

Ohr, M., Halliday, A. N., and Peacor, D. R.: Sr and Nd isotopic evidence for punctuated clay diagenesis, Texas Gulf Coast, Earth Planet. Sc. Lett., 105, 110-126, 1991.

Ohr, M., Halliday, A. N., and Peacor, D. R.: Mobility and fractionation of rare earth elements in argillaceous sediments: Implications for dating diagenesis and low-grade metamorphism, Geochim. Cosmochim. Ac., 58, 289-312, 1994.

Parra, M., Delmont, P., Ferragne, A., Latouche, C., Pons, J. C., and Puechmaille, C.: Origin and evolution of smectites in recent marine sediments of the NE Atlantic, Clay Miner., 20, 335-346, 1985.

Pearce, C. R., Jones, M. T., Oelkers, E. H., Pradoux, C., and Jeandel, C.: The effect of particulate dissolution on the neodymium (Nd) isotope and Rare Earth Element (REE) composition of seawater, Earth Planet. Sc. Lett., 369-370, 138-147, 2013.

Petersen, T. G., Thomsen, T. B., Olaussen, S., and Stemmerik, L.: Provenance shifts in an evolving Eurekan foreland basin: the Tertiary Central Basin, Spitsbergen, J. Geol. Soc., 173, 634-648, https://doi.org/10.1144/jgs2015-076, 2016.

Peucker-Ehrenbrink, B., Miller, M. W., Arsouze, T., and Jeandel, C.: Continental bedrock and riverine fluxes of strontium and neodymium isotopes to the oceans, Geochem. Geophy. Geosy., 11, Q03016, https://doi.org/10.1029/2009GC002869, 2010.

Piotrowski, A. M., Banakar, V. K., Scrivner, A. E., Elderfield, H., Galy, A., and Dennis, A.: Indian Ocean circulation and productivity during the last glacial cycle, Earth Planet. Sc. Lett., 285, 179-189, 2009.

Raczek, I., Stoll, B., Hofmann, A. W., and Jochum, K. P.: Highprecision trace element data for the USGS reference materials BCR-1, BCR-2, BHVO-1, BHVO-2, AGV-1, AGV-2, DTS-1, DTS-2, GSP-1 and GSP-2 by ID-TIMS and MIC-SSMS, Geostandard. Newslett., 25, 77-86, 2001.

Rickli, J., Frank, M., Stichel, T., Georg, R. B., Vance, D., and Halliday, A. N.: Controls on the incongruent release of hafnium during weathering of metamorphic and sedimentary catchments, Geochim. Cosmochim. Ac., 101, 263-284, 2013.

Rickli, J., Hindshaw, R. S., Leuthold, J., Wadham, J. L., Burton, K. W., and Vance, D.: Impact of glacial activity on the weathering of $\mathrm{Hf}$ isotopes - observations from Southwest Greenland, Geochim. Cosmochim. Ac., 215, 295-316, 2017.

Schlegel, A., Lisker, F., Dörr, N., Jochmann, M., Schubert, K., and Spiegel, C.: Petrography and geochemistry of siliclastic rocks from the Central Tertiary Basin of Svalbard - implications for provenance, tectonic setting and climate, Z. Dtsch. Ges. Geowiss., 164, 173-186, 2013.

Setti, M., Marinoni, L., and López-Galindo, A.: Mineralogical and geochemical characteristics (major, minor, trace elements and REE) of detrital and authigenic clay minerals in a Cenozoic sequence from Ross Sea, Antarctica, Clay Miner., 39, 405-421, https://doi.org/10.1180/000985503540143, 2004.

Singer, A.: The paleoclimatic interpretation of clay minerals in sediments - a review, Earth Sci. Rev., 21, 251-293, 1984.

Sionneau, T., Bout-Roumazeilles, V., Biscaye, P. E., Van VlietLanoe, B., and Bory, A.: Clay mineral distributions in and around 
the Mississippi River watershed and Northern Gulf of Mexico: sources and transport patterns, Quaternary Sci. Rev., 27, 17401751, 2008.

Spadea, P. and D'Antonio, M.: Initiation and evolution of intraoceanic subduction in the Uralides: Geochemical and isotopic constraints from Devonian oceanic rocks of the Southern Urals, Russia, Island Arc, 15, 7-25, 2006.

Spielhagen, R. F., Baumann, K.-H., Erlenkeuser, H., Nowaczyk, N. R., Nørgaard-Pedersen, N., Vogt, C., and Weiel, D.: Arctic ocean deep-sea record of northern Eurasian ice sheet history, Quaternary Sci. Rev., 23, 1455-1483, 2004.

Su, N., Yang, S., Guo, Y., Yue, W., Wang, X., Yin, P., and Huang, $\mathrm{X}$ : Revisit of rare earth element fractionation during chemical weathering and river sediment transport, Geochem. Geophy. Geosy., 18, 935-955, https://doi.org/10.1002/2016GC006659, 2017.

Svendsen, J. I. and Mangerud, J.: Holocene glacial and climatic variations on Spitsbergen, Svalbard, Holocene, 7, 45-57, https://doi.org/10.1177/095968369700700105, 1997.

Svendsen, J. I., Alexanderson, H., Astakhov, V. I., Demidov, I., Dowdeswell, J. A., Funder, S., Gataullin, V., Henriksen, M., Hjort, C., Houmark-Nielsen, M., Hubberten, H. W., Ingólfsson, O., Jakobsson, M., Kjær, K. H., Larsen, E., Lokrantz, H., Lunkka, J. P., Lsyå, A., Mangerud, J., Matiouchkov, A., Murray, A., Möller, P., Niessen, F., Nikolskaya, O., Polyak, L., Saarnisto, M., Siegert, C., Siegert, M. J., Spielhagen, R. F., and Stein, R.: Late Quaternary ice sheet history of northern Eurasia, Quaternary Sci. Rev., 23, 1229-1271, 2004.

Tanaka, T., Togashi, S., Kamioka, H., Amakawa, H., Kagami, H., Hamamoto, T., Yuhara, M., Orihashi, Y., Yoneda, S., Shimizu, H., Kunimaru, T., Takahashi, K., Yanagi, T., Nakano, T., Fujimaki, H., Shinjo, R., Asahara, Y., Tanimizu, M., and Dragusanu, C.: JNd-1: a neodymium isotopic reference in consistency with LaJolla neodymium, Chem. Geol., 168, 279-281, 2000.

Taylor, S. R. and McLennan, S. M.: The continental crust: Its composition and evolution, Blackwell Scientific, Boston, Mass., USA, 1985.

Teller, J. T.: Volume and routing of late-glacial runoff from the southern Laurentide ice sheet, Quaternary Res., 34, 12-23, 1990.

Tepe, N. and Bau, M.: Importance of nanoparticles and colloids from volcanic ash for riverine transport of trace elements to the ocean: Evidence from glacial-fed rivers after the 2010 eruption of Eyjafjallajökull Volcano, Iceland, Sci. Tot. Environ., 488-489, 243-251, 2014.

Tessier, A., Campbell, P. G. C., and Bisson, M.: Sequential extraction procedure for the speciation of particulate trace metals, Anal. Chem., 51, 844-851, 1979.

Tricca, A., Stille, P., Steinmann, M., Kiefel, B., Samuel, J., and Eikenberg, J.: Rare earth elements and $\mathrm{Sr}$ and $\mathrm{Nd}$ isotopic compositions of dissolved and suspended loads from small river systems in the Vosges mountains (France), the river Rhine and groundwater, Chem. Geol., 160, 139-158, 1999.

Tütken, T., Eisenhauer, A., Wiegand, B., and Hansen, B. T.: Glacialinterglacial cycles in $\mathrm{Sr}$ and $\mathrm{Nd}$ isotopic composition of Arctic marine sediments triggered by the Svalbard/Barents Sea ice sheet, Mar. Geol., 182, 351-372, 2002.

Veizer, J.: Chemical diagenesis of carbonates: theory and application of trace element technique, in: Stable isotopes in sedimentary geology, edited by: Arthur, M. A., Anderson, T. F., Ka- plan, I. R., Veizer, J., and Land, L. S., vol. 10, 3-1-3-100, Society of Economic Paleontologists and Mineralogists Short Course Notes, Dallas, USA, 1983.

Viers, J. and Wasserburg, G. J.: Behavior of Sm and Nd in a lateritic soil profile, Geochim. Cosmochim. Ac., 68, 2043-2054, https://doi.org/10.1016/j.gca.2003.10.034, 2004.

Viers, J., Roddaz, M., Filizola, N., Guyot, J.-L., Sondag, F., Brunet, P., Zouiten, C., Boucayrand, C., Martin, F., and Boaventura, G. R.: Seasonal and provenance controls on Nd-Sr isotopic compositions of Amazon rivers suspended sediments and implications for $\mathrm{Nd}$ and $\mathrm{Sr}$ fluxes exported to the Atlantic Ocean, Earth Planet. Sc. Lett., 274, 511-523, 2008.

Vogt, C., Knies, J., Spielhagen, R. F., and Stein, R.: Detailed mineralogical evidence for two nearly identical glacial/interglacial cycles and Atlantic water advection to the Arctic Ocean during the last 90000 years, Global Planet. Change, 31, 23-44, 2001.

von Blanckenburg, F. and Nägler, T. F.: Weathering versus circulation-controlled changes in radiogenic isotope tracer composition of the Labrador Sea and North Atlantic Deep Water, Paleoceanography, 16, 424-434, 2001.

Vonk, J. E., Giosan, L., Blusztajn, J., Montlucon, D., Pannatier, E. G., McIntyre, C., Wacker, L., Macdonald, R. W., Yunker, M. B., and Eglinton, T. I.: Spatial variations in geochemical characteristics of the modern Mackenzie Delta sedimentary system, Geochim. Cosmochim. Ac., 171, 100-120, 2015.

Wahsner, M., Müller, C., Stein, R., Ivanov, G., Levitan, M., Shelekhova, E., and Tarasov, G.: Clay-mineral distribution in surface sediments of the Eurasian Arctic Ocean and continental margin as indicator for source areas and transport pathways - a synthesis, Boreas, 28, 215-232, 1999.

Weis, D., Demaiffe, D., Souchez, R., Gow, A. J., and Meese, D. A.: Ice sheet development in Central Greenland: implications from the $\mathrm{Nd}, \mathrm{Sr}$ and $\mathrm{Pb}$ isotopic compositions of basal material, Earth Planet. Sc. Lett., 150, 161-169, 1997.

Wickert, A. D.: Reconstruction of North American drainage basins and river discharge since the Last Glacial Maximum, Earth Surf. Dynam., 4, 831-869, https://doi.org/10.5194/esurf-4-831-2016, 2016.

Wilson, D. J., Piotrowski, A. M., Galy, A., and Clegg, J. A.: Reactivity of neodymium carriers in deep sea sediments: Implications for boundary exchange and paleoceanography, Geochim. Cosmochim. Ac., 109, 197-221, 2013.

Winkler, A., Wolf-Welling, T. C. W., Stattegger, K., and Thiede, J.: Clay mineral sedimentation in high northern latitude deep-sea basins since the Middle Miocene (ODP Leg 151, NAAG), Int. J. Earth Sci., 91, 133-148, 2002.

Wooden, J. L., Czamanske, G. K., Fedorenko, V. A., Arndt, N. T., Chauvel, C., Bouse, R. M., King, B.-S. W., Knight, R. J., and Siems, D. F.: Isotopic and trace-element constraints on mantle and crustal contributions to Siberian continental flood basalts, Noril'sk area, Siberia, Geochim. Cosmochim. Ac., 57, $3677-$ 3704, 1993.

Ziaja, W. and Pipała: Glacial recession 2001-2006 and its landscape effects in the Lindströmfjellet-Håbergnuten mountain ridge, Nordenskiöld Land, Spitsbergen, Pol. Polar Res., 28, 237-247, 2007. 